Amasya Ilahiyat Dergisi - Amasya Theology Journal

ISSN 2667-7326 | e-ISSN 2667-6710

Haziran / June 2021, 16: 519-550

\title{
Sa'düddîn Teftezânî'ye Göre Şefaatin İmkân ve Keyfiyeti
}

\section{Hasan TÜRKMEN}

Dr., Akyurt Nevzat Hüseyin Tiryaki Mesleki ve Teknik Anadolu Lisesi Din Kültürü ve Ahlak Bilgisi Öğretmeni

Ph.D, Religious Culture and Moral Knowledge Teacher in Akyurt Nevzat Hüseyin Tiryaki High School of the Vocational and Technical Anatolian Ankara, TURKEY

h_turkmen1979@hotmail.com

orcid.org/0000-0002-6101-9552

\section{Makale Bilgisi / Article Information}

Makale Türü / Article Types: Araştırma Makalesi / Research Article

Geliş Tarihi / Received: 8 Ocak / January 2021

Kabul Tarihi / Accepted: 29 Nisan / April 2021

Yayın Tarihi / Published: 30 Haziran / June 2021

Yayın Sezonu / Pub. Date Season: Haziran / June

Sayı / Issue: 16 Sayfa / Pages: 519-550

Atıf / Cite as: Türkmen, Hasan. "Sa'düddîn Teftezânî'ye Göre Şefaatin İmkân ve Keyfiyeti [Possibility and Nature of The Intercession According to Sa'd aldîn al-Taftâzânî]". Amasya Illahiyat Dergisi-Amasya Theology Journal 16 (June 2021): 519-550.

https://doi.org/10.18498/amailad.856687.

İntihal / Plagiarism: Bu makale, en az iki hakem tarafından incelendi ve intihal içermediği teyit edildi. / This article has been reviewed by at least two referees and scanned via a plagiarism software.

Copyright $($ C Published by Amasya Üniversitesi, İlahiyat Fakültesi / Amasya University, Faculty of Theology, Amasya, 05100 Turkey. All rights reserved. https://dergipark.org.tr/amailad. 
520 | H. TÜRKMEN / Sa' düddîn Teftezânî'ye Göre Şefaatin İmkân ve Keyfiyeti

\section{Possibility and Nature of The Intercession According to Sa'd al-dîn al- Taftâzânî}

\section{Abstract}

The belief of intercession is closely related with the idea of eternal bliss and salvation in all religions. In these religions, which teach that true and eternal happiness will be in the hereafter, intercession is rather associated with hereafter. This belief, which exists with its distinctive appearances in Judaism and Christianity, has been a subject that shaped the belief World of Arabs during the period of Ignorance (Jahiliyya), who were the first addresses of the Qur'an. In this sense, although they had the idea of a transcendent and sublime creator, they claimed that both the angels and the idols they worshiped as these angels' images would intercede about them and bring them closer to God. So much so that they started to worship these lifeless images by making sculptures of angels they saw close to Allah and gave them feminine names. In a sense, they thought that God could not be directly communicated, as they regarded God as a remote, inaccessible, and sublime being incompatible with their world of thought, and they mediated their idols with God in order to convey their needs and demands. As a result, they turned to the idols, whom they thought to maintain the connection between them and Allah, with the aim of being sure of their fear and wrath or seeking benefit and help, and they expected intercession. However, the Qur'an found it necessary to change their claim completely contrary to the principle of tawhid, which is the basis of the divine religions and their common call. Because this understanding, which means that God is a partner in His lordship (rubbiyet), attributes, actions, and property, also means. His distribution and sharing of authority. Whereas the use of authority and power belongs solely and completely to God. Undoubtedly, all beings are under His control and sovereignty. There is no independent field from Him. The laws and principles of the administration and administration of both this world and the hereafter belong to Him. Thefore, there is no being in His sight that can intercede without His permission and will. As a matter of fact, when looking at the passages, on the one hand Allah strongly, denies the intercession expectation of the polytheist society; on the other hand, it attributes this authority belonging to it to some criteria. Obviously this situation has led to the discussion of how intercession before the Islamic sects and their followers. In fact, the course and focal point of the debate is the question of what the state of the great sinners who die without repentance will be in the hereafter. In other words, the type and size of the relationship between faith and action determined the approach of the parties to the issue of intercession. 
In this study, the views and thoughts of Sa'd al-dîn al-Taftâzânî (d. 792/1390), one of the late Ashârî scholars, on the relationship between faith and action that shape and guide the issue will be discussed. More precisely, his explanations and evaluations about the situation of the person who committed a great sin in the world and the hereafter will be touched upon, since it constitutes the main line of the issue. Then, in the context of its scope and scope of meaning, intercession's justifications regarding the existence of intercession in the hereafter will be given. While all these are being done, since the author-based issue will be examined specifically in al-Taftâzânî, it is inevitable that this study contains some limitations and determinations. Accordingly, the study will be narrowed and limited in terms of subject, source and method. Accordingly, the study will be narrowed and limited in terms of subject, source and method. While the major sin and intercession issues, which are directly related and related to each other, will be discussed under sub-headings, only original and basic sources, namely the author's own works, will be referred. Descriptive, argumentation and comparison method will be followed in the study as a method. However, in this process, Mu'tazila's approach to these two issues and his responses to this school will be discussed comparatively, which the author regards as an enemy in his works. Apart from that, the opinions and thoughts of other kalam schools in addition to the school to which the author is a member will not be included separately in sub-headings.

Keywords: Kalam, Qur'an, Tawhid, al-Taftâzânî, Intercession.

\section{$\ddot{\mathrm{O} z}$}

\section{Sa' düddîn Teftezânî'ye Göre Şefaatin İmkân ve Keyfiyeti}

Şefaat inancı, tüm dinlerin ebedî saadet ve kurtuluşa erme fikriyle yakından ilişkilidir. Gerçek ve ebedî mutluluğun ahirette olacağını öğreten bu dinlerde şefaat, daha ziyade ahiretle irtibatlandırılmaktadır. Yahudilik ve Hıristiyanlık'ta kendilerine özgü farklı görünümleriyle birlikte var olan bu inanç, Kur'ân'ın ilk muhatapları olan Câhiliye dönemi Arapların da inanç dünyasını şekillendiren bir konu olmuştur. Bu anlamda her ne kadar onlar, aşkın ve yüce olan bir yaratıcı fikrine sahip olsalar da gerek melekleri gerekse onların suretleri olarak kabul edip tapındıkları putların kendileri hakkında şefaatçi olacaklarını ve kendilerini Allah'a yaklaştıracaklarını iddia etmişlerdir. Öyle ki Allah'a yakın gördükleri meleklerin heykellerini yaparak bu cansız suretlere tapınmaya başlamışlar ve onlara dişil isimler vermişlerdir. Bir bakıma onlar, Allah'ı uzak, erişilemez ve düşünce dünyalarına sığdırılamaz üstün bir Varlık olarak 
gördüklerinden kendisiyle doğrudan iletişime geçilemeyeceğini düşünmüşler ve putları, ihtiyaçları ve taleplerini iletmek üzere Allah ile aralarında aracı kılmışlardır. Neticede kendileri ile Allah arasında irtibatı sağladığını zannettikleri putlara, korku ve gazabından emin olma yahut fayda ve yardım görme amacıyla yönelerek şefaat beklentisi içerisine girmişlerdir. Ancak Kur'ân, onların bu iddiasını, bilhassa ilahî dinlerin esasını oluşturan ve ortak çağrısı olan tevhid prensibine tamamen aykırı bulup köklü biçimde değiştirilmesini zorunlu görmüştür. Zira Allah'ın rubûbiyetinde, sıfatlarında, fiillerinde ve mülkünde ortağı olması anlamına gelen bu anlayış, aynı zamanda O'nun yetki dağılımı ve paylaşımı yapması demektir. Oysa yetki ve güç kullanımı yalnızca ve tamamen Allah'a aittir. Şüphesiz tüm varlıklar O'nun kontrolü ve hükümranlığı altındadır. O'ndan bağımsız bir alan yoktur. Hem bu dünyanın hem de ahiretin sevk ve idaresinin yasaları ve ilkeleri O'na aittir. Dolayısıyla O'nun izni ve iradesi olmadan O'nun katında şefaat edebilecek hiçbir varlık yoktur. Nitekim nasslara bakıldığında Allah, bir taraftan Müşrik toplumun şefaat beklentisini şiddetle reddederken; diğer taraftan kendisine ait olan bu yetkiyi bazı kriterlere bağlamıştır. Açıkçası bu durum, İslâm fırkaları ve müntesipleri nezdinde şefaatin varlığı veya yokluğundan ziyade nasıl gerçekleşeceği ve kimleri kapsayacağı noktasında tartışılmasına neden olmuştur. Esasında tartışmanın seyrini ve odak noktasını, tövbe etmeden ölen büyük günah sahibi kimselerin ahiretteki durumlarının ne olacağı sorunu oluşturmaktadır. Başka bir deyişle iman ile amel arasındaki ilişki türü ve boyutu, tarafların şefaat meselesine yaklaşımını belirlemiştir.

Bu çalışmada, müteahhirûn dönemi Eş'ârî âlimlerinden Sa'düddîn Teftâzânî'nin (öl. 792/1390), meseleye şekil ve yön veren iman-amel ilişkisine dair görüş ve düşünceleri üzerinde durulacaktır. Daha doğrusu meselenin ana damarını oluşturmasından ötürü büyük günah işleyen kimsenin dünya ve ahiretteki durumu hakkında onun açıklama ve değerlendirmelerine temas edilecektir. Ardından anlam alanı ve kapsamı bağlamında şefaatin ahiretteki varlığına ilişkin onun aklî ve naklî açıdan temellendirmelerine yer verilecektir. Tüm bunlar yapılırken Teftâzânî özelinde müellif bazlı mesele irdeleneceğinden bu çalışmanın bazı sınırlandırmalar ve belirlemeler barındırması kaçınılmazdır. Buna bağlı olarak çalışma, konu, kaynak ve yöntem bakımından daraltılmış ve sınırlı tutulmuş olacaktır. Birbiriyle doğrudan alakalı ve ilişkili olan büyük günah ve şefaat konuları alt başlıklar hâlinde ele alınırken yalnızca özgün ve temel kaynaklara yani müellifin kendi eserlerine müracaat edilecektir. Yöntem olarak çalışmada, deskriptif, argümantasyon ve karşılaştırma metodu izlenecektir. Fakat bu süreçte müellifin, eserlerinde hasım 
olarak görüp muhatap aldığı Mu'tezile'nin bu iki konu hakkındaki yaklaşımını ve kendisinin de bu ekole yönelik verdiği yanıtlara mukayeseli olarak değinilecektir. Onun haricinde müellifin mensubu olduğu ekolün yanı sıra diğer kelâm okullarının bu iki konuya dair görüş ve düşüncelerine alt başlıklar hâlinde ayrı ayrı olarak yer verilmeyecektir.

Anahtar Kelimeler: Kelam, Kur'ân, Tevhit, Teftâzânî, Şefaat.

\section{Giriş}

Şefaat olgusu ne bedîhî ne tecrübî ne de nazar ve istidlalle elde edilen akliyyâta ait konulardan birisidir. Tam aksine kıyamet, kabir sorgusu, haşr, cennet, cehennem ve ru'yetullah gibi gayp konuları arasında yer alan semiyyât konularındandır. Zira bu olgu, ahiret ahvalinden olup ilahî bildirime ve Hz. Peygamber'in haber vermesine bağlı bir meseledir. Bu mesele hakkında bilgi sahibi olunabilmesi için her şeyden önce ilahî bilginin yol göstericiliği kaçınılmazdır. Nitekim duyu verileri ve akılla ahiret ahvali hakkında bilgi sahibi olunması mümkün değildir. O hayata dair bilgiler yalnızca naklî delile dayanır. $\mathrm{Bu}$ nedenle akıl, bu tür konularda onun bilgisine ve yönlendirmesine muhakkak surette gereksinim duyar.

Öte yandan Kur'ân'in ilk muhatapları olan Câhiliye dönemi Arapları, her ne kadar aşkın ve mutlak olan Yüce bir Yaratıcı fikrine ${ }^{1}$ sahip olsalar da kendilerini Allah'a yaklaştırmaları ${ }^{2}$ ve O'nun katında şefaatçi olmaları ${ }^{3}$ için meleklere ulûhiyet atfetmişlerdir. ${ }^{4}$ Öyle ki Allah'a yakın gördükleri meleklerin heykellerini yaparak bu cansız suretlere tapınmaya başlamışlar ve onlara dişil isimler vermişlerdir. ${ }^{5}$ Bir bakıma

1 el-Mü'minûn 23/84-89; el-Ankebût 29/61, 63; Lokmân 31/25; ez-Zümer 39/38; ezZuhruf 43/9, 87 .

2 ez-Zümer 39/3.

3 Yûnus 10/18.

4 Mekkeli Müşrikler, Allah'ın kızları olarak niteledikleri Lât, Menât ve Uzza (Necm, 53/19-21) putlarının yanı sıra cinleri de O'na ortak koşmuşlardır. Nitekim kendi zanlarınca Allah'a oğul ve kızlar yakıştırmışlardır. Oysa Allah, onların bu yakıştırmalarından uzak ve yücedir. Nasıl olur da eşi, benzeri ve dengi olmadığı (Meryem 19/65; eş-Şûrâ 42/11; el-İhlâs 114/1,4) gibi, doğmayan ve doğurmayan (elİhlâs, 114/3) bir yaratıcının çocuğu olabilir? el-En'âm 6/100-101.

5 en-Necm 53/27. Yüce Allah, meleklere dişil isimler veren bu kimselerin ahirete inanmadıklarını (en-Necm 53/27) ve onların böyle yaparak zan ve nefislerinin 
onlar, Allah'ı uzak, erişilemez ve düşünce dünyalarına sığdırılamaz Üstün bir Varlık olarak gördüklerinden kendisiyle doğrudan iletişime geçilemeyeceğini düşünmüşler ve putları, ihtiyaç ve taleplerini iletmek üzere Allah ile aralarında aracı kılmışlardır. Neticede kendileri ile Allah arasında irtibatı sağladığını zannettikleri putlara, korku ve gazabından emin olma ya da fayda ve yardım görme amacıyla yönelerek ${ }^{6}$ şefaat beklentisi içerisine girmişlerdir. ${ }^{7}$

Allah'ın rubûbiyetinde, sıfatlarında, fiillerinde ve mülkünde ortağ 1 olması anlamına gelen bu anlayış, aynı zamanda O'nun yetki dağılımı ve paylaşımı yapması demektir. Oysa Kur'ân'da beyan edildiği üzere bir başkasına fayda ya da zarar vermek şöyle dursun, kendilerine dahi fayda veya zarar sağlayamayan ne melekler ne de onların suretleri olan putlar, ${ }^{8}$ şefaat yetkisine sahiptir. İrade ve güç yalnızca ve tamamen Allah'a aittir. Zira tüm varlıklar O'nun kontrolü ve hükümranlığ altındadır. ${ }^{9}$ O'ndan bağımsız bir alan yoktur. Hem bu dünyanın hem de ahiretin sevk ve idaresinin yasaları ve ilkeleri O'na aittir. ${ }^{10}$ Dolayısıyla Allah'ın izni ve iradesi olmadan O'nun katında şefaat edebilecek hiçbir varlık ve güç yoktur. ${ }^{11} \mathrm{Bu}$ manada fâil-i muhtar bir Varlık olarak Yüce Yaratıcı, dilediği kimselere şefaat yetkisini verdiği gibi dilediği kullarını da bu şefaaten yararlandırır. Bu yönüyle şefaat, bütünüyle ve yalnızca O'nun iznine ve uygun görmesine bağlidır. ${ }^{12}$ Kuşkusuz haşyet ve ta'zîmleri gereği Allah'a sürekli boyun eğen ve kendilerine verilen

arzularına uyduklarını beyan eder. Ayrıca O, bu kimselerin, kendisine karşı yalan uyduran ve ayetlerini yalanlayan iflah olmaz zalimler olduğunu bildirir. Yûnus 10/17. Yine Rab, "zalimler" olarak nitelediği bu kimselerin, kıyamet gününde ne dostu ne de şefaatçisi olacağını haber vermektedir. el-Mü'min 40/18; ez-Zuhruf 43/86.

6 Akif Akay, İslâm İnancında Şefaat (Ankara: Akçă̆ Yayınları, 2016), 40.

7 Müşrik toplum, Allah'ın dûnunda tanrılar edinerek Allah'ı sever gibi o tanrıları sevmekte (el-Bakara 2/165), kendilerine fayda ya da zarar verebileceklerine (Hûd 11/54; el-Mülk 67/20) ve yardım edebileceklerine (Yâsîn 36/75) inanmaktadır.

8 el-En'âm 6/94; Yûnus 10/18; er-Rûm 30/13.

9 ez-Zümer 39/44.

10 el-A' râf 7/54.

11 el-Bakara 2/255; Yûnus 10/3; Tâhâ 20/109; Sebe 34/23.

12 Muzaffer Barlak, “İbn Teymiyye'nin Felsefî Yöntem Eleştirisi ve Müslüman Filozofları Tekfir Etme Gerekçeleri", The Journal of Academic Social Science Studies 13/81 (Güz 2020), 375. 
emirleri aynen yerine getiren melekler ${ }^{13}$ de sadece O'nun dilediği ve kendilerinden razı olduğu kimseler için izin vermesiyle şefaat edebileceklerdir. ${ }^{14}$

Allah, bir taraftan Müşrik toplumun şefaat beklentilerini hiçbir esneklik ve taviz vermeksizin şiddetle reddederken; diğer taraftan kendisine ait olan bu yetkiyi bazı kriterlere bağlamaktadır. Kuşkusuz şefaatin konu edildiği Kur'ân ayetlerine bakıldığında, gerek kendilerine şefaat edeceklerini zannettikleri meleklerin suretleri olan putlara tapan Müşriklerin gerekse ahirette peygamberlerinin sadece kendilerine şefaat edeceğini iddia eden İsrailoğullarının şefaat beklentilerini boşa çıkaracak biçimde mutlak olarak şefaatin reddedildiği ayetlerle ${ }^{15}$ karşılaşıldığı gibi, istisna getirilerek şefaate aracı olacaklar ${ }^{16}$ ve şefaat edilecekler ${ }^{17}$ açısından şefaati Allah'ın iznine bağlayan âyetlere de rastlanmaktadır. Fakat istisna getirilen bu ayetlerde, kimin kimlere nasıl şefaat edeceği hususu açıkça belirtilmemektedir.

Açık kapı bırakılan bu durum, İslâm fırkaları ve müntesipleri nezdinde şefaatin varlığından ziyade nasıl gerçekleşeceği ve kimleri kapsayacağı ekseninde tartışılmasına neden olmuştur. Bu noktada kimlere şefaat edileceğine ilişkin dinin ikinci temel kaynağı olan hadîslerin varlığı da yadsınamaz bir gerçektir. Her ne kadar farklı biçimde tevil etseler de Mu'tezile'nin kabul ettiği ve Ehl-i Sünnet âlimlerinin güçlü dayanak olarak görüp sımsıkı tutunduğu büyük günah sahipleri için şefaatin varlığına dönük hadîsler, kavrama yüklenen anlamları ve konunun mahiyetini şekillendirmede etkin bir role sahiptir.

Ancak tartışmanın seyrini ve odak noktasını, tövbe etmeden ölen kebâir sahibi kimselerin ahiretteki durumlarının ne olacağı sorunu oluşturmaktadır. Başka bir deyişle iman ile amel arasındaki ilişki türü,

13 el-A'râf 7/206; er-Ra'd 13/13; en-Nahl 16/49-50; el-Enbiyâ 21/19, 27; es-Saffât 37/166; ez-Zümer 39/75; el-Mü'min 40/7; Fussilet 41/38; eş-Şûrâ 42/5; et-Tahrîm 66/6.

14 el-Enbiyâ 21/28; en-Necm 53/26.

15 el-Bakara 2/48, 123, 254; el-En'âm 6/51, 70, 94; el-A'râf 7/53; Yûnus 10/18; eş-Şuarâ 26/100-101; er-Rûm 30/13; Yâsîn 36/23; ez-Zümer 39/43-44; el-Mü'min 40/18; elMüddessir 74/48.

16 el-Bakara 2/255; Yûnus 10/3; Meryem 19/87; Tâhâ 20/109; es-Sebe' 34/23; ez-Zuhruf $43 / 86$.

17 el-Enbiyâ 21/28; en-Necm 53/26. 
tarafların şefaat meselesine yaklaşımını belirlemiştir. Bu aşamada her şeyden önce müteahhirûn dönemi Eş'ârî âlimlerinden Sa'düddîn Teftâzânî'nin (öl. 792/1390) meseleye şekil ve yön veren iman-amel ilişkisine dair görüş ve düşünceleri üzerinde durulacaktır. Daha doğrusu meselenin ana damarını oluşturmasından ötürü büyük günah işleyen kimsenin dünya ve ahiretteki durumu hakkında onun açılama ve değerlendirmelerine temas edilecektir. Ardından anlam alanı ve kapsamı bağlamında şefaatin ahiretteki varlığına ilişkin onun aklî ve naklî açıdan temellendirmelerine yer verilecektir.

Teftâzânî özelinde müellif bazlı mesele irdeleneceğinden bu çalışmanın bazı sınırlandırmalar ve belirlemeler barındırması kaçınılmazdır. Bu amaçla çalışma, kuşkusuz konu, kaynak ve yöntem bakımından daraltılmış ve sinırlı tutulmuş olacaktır. Birbiriyle doğrudan bağlı ve ilişkili olan büyük günah ve şefaat konuları alt başlıklar hâlinde ele alınırken yalnızca özgün ve temel kaynaklara yani müellifin kendi eserlerine müracaat edilecektir. Yöntem olarak çalışmada, desktriptif, argümantasyon ve karşılaştırma metodu izlenecektir. Fakat bu süreçte müellefin, eserlerinde hasım olarak görüp muhatap aldığı Mu'tezile'nin bu iki konuya dair yaklaşımını ve kendisinin de bu ekole yönelik verdiği yanıtlara mukayeseli olarak değinilecektir. Onun haricinde müellifin müntesibi olduğu ekolün yanı sıra diğer kelâm okullarının bu iki konu hakkındaki görüş ve düşüncelerine alt başlıklar hâlinde ayrı ayrı yer verilmeyecektir.

\section{Teftâzânî'de İman-Amel İlişkisi}

Kelâm ilminin temel konularından olan iman-amel ilişkisi, başlangıç ve çıkış itibariyle siyasî ve sosyal bir mesele olmasına rağmen zaman içerisinde Müslümanların birbirlerinin imanlarını sorgulamasıyla birlikte hilafet tartışmasının ötesine geçerek sancılı süreci ifade eden bir inanç meselesine evirilmiştir. Bu yönüyle $\mathrm{Hz}$. Peygamber'in vefatının ardından hilafet tartışmasına bağlı olarak Müslüman toplumlarda tartışılan ve köklü ayrışmaya neden olan ilk sorun hükmünde değerlendirilebilir. Nitekim sorun, siyasî ve sosyo-kültürel çatışmalarla irtibatlı olduğu kadar, hicri ikinci yüzyıldan itibaren oluşum sürecine girmeye başlayan mezheplerin, kendi içinde alt konulara ayrılan ${ }^{18}$ bu

18 İman-amel ilişkisi, temel bir konu olarak büyük günah işleyen kimsenin dünya ve ahiretteki durumu ve ona bağlı olarak iman-küfür sınırı başta olmak üzere imanİslâm ilişkisi, imanda artma ya da azalma, imanda istisna, kategorik iman ayrımını 
meseleye dair görüşleri ve birbirlerine karşı sert, keskin ve kırıcı üsluplarının yanı sıra ayrıştırıcı, dışlayıcı ve ötekileştirici söylemleriyle de doğrudan alakalıdır.

İman-amel ilişkisi, aslında mümin kimsenin büyük günah işledikten sonra yine de o vasfı taşıyıp taşımadığı sorunudur. Bu anlamda ebedî saadete ve kurtuluşa ermek için yalnızca iman etmek yeterli midir, yoksa onun amellerle pratik yaşamın içinde belirginleşmesi kaçınılmaz mıdır? ${ }^{19}$ Başka bir söyleyişle imanın unsurlarını neler oluşturmaktadır? Daha doğrusu imanın aslî unsur ya da unsurları nelerdir ve bunların birbirleriyle ilişki boyutu ne düzeydedir? Bilhassa sâlih amellerin noksanlığı yahut azlığı, kişideki imana zarar verir mi? Hatta bu amellerin olmaması, imanın varlığını ne derece etkiler? Tüm bu sorular, imanın tanımı ve mahiyeti ekseninde yanitları aranan öncelikli sorulardır.

Bu çerçevede lügatte "tasdik" manasına gelen ve onun ismi olan imanın, ${ }^{20}$ e-m-n "آمن" kök fiilinin dönüşlülük ve geçişlilik için kullanılan "فعال:if'âl" vezninde masdar oluşunu öne çıkaran Teftâzânî, "ب" ve "ل" edatlariyla bu fiilin, "itiraf ve isteyerek boyun eğme" anlamların içerdiğini belirtir. ${ }^{21}$ Ona göre iman, bir şeyin doğru ve gerçek olduğunun kabulü anlamına geldiğinden onun kullanımı muhtelif açılardan taalluk eder. ${ }^{22}$ Daha açık bir söyleyişle tasdik edilecek olan hususların bilinmesi gereken tüm yönleriyle benimsenmesidir. Sözgelimi, "Allah'a iman ettim" derken; burada sadece O'nun varlığına inanmak yeterli değildir. Bunun dışında O'nun yegâneliğine, kemâl sıfatlarla vasıflandığına, öte

ifade eden tahkikî ve taklidî iman gibi kendi içinde birçok alt konuları ihtiva etmektedir. Ayrıca şemsiye konumunu üstlenen bu temel konu, büyük ve küçük günahlar, tekfîr, ebedî azap, tövbe ve şefaat gibi konularla da doğrudan ilintilidir.

19 Hasan Türkmen, "Şemsuddîn es-Semerkandî'de Îman-Amel İlişkisi", Aksaray Üniversitesi İslami İlimler Fakültesi Dergisi 4/7 (2017 Haziran), 22.

20 Mes'ûd b. Ömer b. Abdullah eş-Şehîr bi Sa'duddîn et-Teftâzânî, Şerhu'l-mekâsıd, thk. İbrâhîm Şemsüddîn (Beyrut: Dârü'l-kütübi'l-ilmiyye, 2011), 3/417, 422, 426; Tehzîbü'lmantık ve'l-kelâm, thk. Şeyh Abdülkâdir Ma'rûf el-Kürdî (Mısır: Matbaatü's-sa'de, 1330/1912), 113, 115; Mekâsıdu'l-kelâm fì 'akâidi'l-islâm, çev. İrfan Eyibil (İstanbul: Türkiye Yazma Eserler Kurumu Başkanlığı Yayınları, 2019), 708; Şerhu'l-'akâid, çev. Talha Hakan Alp (İstanbul: Marmara Üniversitesi İlahiyat Vakfı Yayınları, 2017), 265, 271.

21 Teftâzânî, Şerhu'l-mekâsıd, 3/417, 419; Mekâsıdu'l-kelâm fî 'akâidi'l-islâm, 708.

22 Teftâzânî, Mekâsıdu'l-kelâm fì 'akâidi'l-islâm, 708. 
528 | H. TÜRKMEN / Sa' düddîn Teftezânî'ye Göre Şefaatin İmkân ve Keyfiyeti

yandan teşbih, eksik ve kusur çağrıştıran sıfatlardan münezzeh olduğuna da inanmak gerekir.

Buradan hareketle Teftâzânî, dinî literatürde imanı; Hz. Peygamber'in Allah katından getirdiği zaruri olarak bilinen konulardan icmâlen sabit olanlara icmâlen, tafsilatlı olanlara da ayrıntılı olarak kalben tasdik şeklinde tanımlamaktadır. ${ }^{23}$ Buna bağlı olarak mümin, Allah'ın emir ve nehiylerine muhatap olan yani onlara karşı şüphe ve tereddüt/duraksama duymaksızın tasdik eden kimsedir. ${ }^{24}$ Nitekim imanın özünü ve esasını teşkil eden tasdikte muteber olan ise kalbin fiilidir. ${ }^{25}$ Zira bu tasdik, iman edilmesi gereken hususların bilinmesinin ötesinde kişinin gücü ve iradesi doğrultusunda kesbettiği tercih ve yöneliminin açığa çıkmasıdır. ${ }^{26}$ Daha doğrusu onların kabulüne yönelik kalpte bir güven ve teslimiyet hâlinin oluşmasıdır. ${ }^{27} \mathrm{Bu}$ yönüyle zihinsel bir süreç olan kalbî tasdik, hakikatin içselleştirilmesi ve gönülden bağlanılması noktasında hem bilgi ve marifetten hem de mantıktaki tasavvurun karşılığ 1 olan tasdikten farklı olup onların üzerine ilave bir aşamayı içerir.

$\mathrm{Bu}$ aşama, aynı zamanda kalpte neyin gizli olduğu insanlar tarafından bilinmesi mümkün olmadığından ikrarı yani orada bulunanı açıkça dile getirmeyi gerektirir. Kuşkusuz dış müdahalelere kapalı olan kalpteki tasdikin tanınması ve varlık sahnesine çıkması kaçınılmaz bir sonuçtur. ${ }^{28}$ Nitekim can ve malın korunması, ${ }^{29}$ namaz kıldırması, cenaze namazının kılınması, Müslüman mezarlığına defnedilmesi, öşür ve zekâttan pay verilmesi kabilinden bir Müslümana dünyevî hükümlerin uygulanabilmesi noktasında ikrar şarttır. Bu nedenle onun açıkça

23 Teftâzânî, Tehzîbü'l-mantık ve'l-kelâm, 113; Şerhu'l-mekâsıd, 3/426.

24 Teftâzânî, Tehzîbü'l-mantık ve'l-kelâm, 115.

25 Teftâzânî, Tehzîbü'l-mantık ve'l-kelâm, 113; Şerhu'l-mekâsıd, 3/426; Şerhu'l-'akâid, 269. Teftâzânî'ye göre, imanın kalbin fiili olduğuna dair el-Mâide 5/40, en-Nahl 16/106, elHucurât 49/14, el-Mücâdele 58/22 ve el-Mümtehine $60 / 10$ ayetler ile peygamberimizin şu sözleri delalet etmektedir: "Allah'ım! Kalbimi dinin üzerine sabit kıl." (Tirmizî, Kader, 7; İbn Mâce, Duâ, 2). "'Kalbinde hardal tanesi kadar iman olan kimse cennete girecektir." (Buhârî, İman, 15; Ahmed b. Hanbel, Müsned, 3/144). Bk. Teftâzânî, Şerhu'l-mekâsıd, 3/423-424.

26 Teftâzânî, Tehzîbü'l-mantık ve'l-kelâm, 115; Şerhu'l-mekâsıd, 3/425, 427, 429; Mekâsıdu'lkelâm fì 'akâidi'l-islâm, 714, 716 .

27 Teftâzânî, Şerhu'l-'akâid, 266.

28 Teftâzânî, Şerhu'l-'akâid, 269.

29 Teftâzânî, Şerhu'l-mekâsıd, 3/423. 
söylenmesi ve gözler önüne serilmesi bakımından bir zorunluluk olup gizlenmesi doğru değildir. ${ }^{30}$ Aksi takdirde bir kimsenin bu dünyada Müslüman olup olmadığına ilişkin hüküm verilemez. Dolayısıyla nasıl ki imanın ibadetin şartı olduğu hususunda icmâ söz konusu ise, amel etmeden önce kalbiyle tasdik eden bunu açıça dile getiren kimsenin mümin olduğu hususunda da görüş birliği ve uzlaşı hâkimdir. ${ }^{31}$

Ne var ki gerek ikrah hâli ${ }^{32}$ gerekse diliyle söylediği halde kalbiyle tasdik etmeyen münafıklar ${ }^{33}$ ile iman ettiklerini iddia eden Bedevîlere dönük Allah'ın beyanı, ${ }^{34}$ tasdikin hiçbir zaman ihmal edilemeyecek ve geçerliliğini yitirmeyecek bir rükün olduğunu gösterir. ${ }^{35}$ Keza bu durum, ikrarın tasdikin önüne asla geçemeyeceğine de delalet eder. ${ }^{36}$

Buna karşın ameller ise, imanın hakikatinden olmayıp ona aktarılamaz. Zira iman, kalbe ait özel bir durumu yansıttığından tasdik anlamı dişında başka bir mana için kullanılmamıştır. ${ }^{37}$ Nitekim amellerin kabul şartının iman olması hem de müminlere yönelik emir ve nehiy hitapları, ${ }^{38}$ amelin imanın var olmasından sonra söz konusu olduğunu gösterir. ${ }^{39}$ Ayrıca imanın tasdik ve ikrardan ibaret olduğu ve

30 Teftâzânî, Şerhu'l-mekâsıd, 3/421.

31 Teftâzânî, Şerhu'l-mekâsıd, 3/432.

32 Cebir ve tehditle kişiyi razı olmadığı bir söz veya davranışa zorlamak anlamına gelen ikrah, en-Nahl 16/106. ayette de görüldügü üzere inkâra zorlanan kimselerin kalpleri imanla dolu olduğu sürece söyledikleri sözlerin imanlarına zarar vermeyeceği buyrulmaktadır. Bekir Topaloğlu - İlyas Çelebi, Kelâm Terimleri Sözlüğü (İstanbul: İSAM Yayınları, 2015), "İkrah", 147.

33 "İnsanlardan kimileri vardır ki, inanmadıkları halde 'Allah'a ve ahiret gününe inandık' derler." Bakara, 2/8.

34 "Bedevîler 'iman ettik" dediler. De ki: 'siz iman etmediniz ama boyun eğdik/teslim olduk' deyin. Henüz iman, kalplerinize yerleşmedi..." el-Hucurât 49/14.

35 Teftâzânî, Şerhu'l-'akâid, 268.

36 Teftâzânî, Tehzîbü'l-mantık ve'l-kelâm, 116.

37 Teftâzânî, Şerhu'l-mekâsıd, 3/432, 433; Tehzîbü'l-mantık ve'l-kelâm, 115.

38 İlgili ayetler için bk. el-Bakara 2/104, 153, 172, 183, 254, 264, 267, 278, 282; Âl-i İmrân 3/102, 118, 130, 200; en-Nisâ 4/19, 29, 43, 59, 71, 94, 135, 144; el-Mâide 5/1, 2, 6, 8, 11, 35, 51, 87, 90-95, 101, 104-105; el-Enfâl 8/15-16, 20, 27, 29, 45-46; et-Tevbe 9/23, 27, 34, 119, 123; el-Hacc 22/77-78; en-Nûr 24/21, 27, 58; el-Ahzâb 33/9, 41, 49, 53, 69-70; elHucurât 49/1, 2, 6, 11, 12; el-Hadîd 57/28; el-Mücâdele 58/11, 12; el-Haşr 59/18; elMümtehine 60/1, 10; es-Saf 61/2, 10, 14; el-Cum'a 62/9; et-Tegâbün 64/14; et-Tahrîm $66 / 6,8$.

39 Teftâzânî, Şerhu'l-mekâsıd, 3/432, 433, 434; Tehzîbü'l-mantık ve'l-kelâm,115. 
530 | H. TÜRKMEN / Sa' düddîn Teftezânî'ye Göre Şefaatin İmkân ve Keyfiyeti

onda amele yer olmadığı da gayet açıktır. Bu minvalde iman ile amelin aynı ayet içerisinde peş peşe geldiği nasslarda ${ }^{40}$ Allah, önce imanı dile getirip akabinde sâlih ameli ona atfettiği için bu durum, iman ile amelin birbirinden farklı oluşuna delalet eder. Çünkü bu nasslardaki atıf harfleri, mugayereti/aykırılığı gerektirir. ${ }^{41}$ Şayet amel imanın bir rüknü olmuş olsaydı, bu naslarda "iman edenler" denilmesinin ardından bunun üzerine "sâlih amel işleyenler" denilmesine gerek kalmazdı. Böyle olmasaydı, tekrar olmuş olurdu ki, tekrar da aslın aksine bir durum içerir. ${ }^{42}$

Yine kimi ayetlerde, ${ }^{43}$ iman ile masiyet içeren kimi davranışlar bir arada kullanılmaktadır. Şayet iman taatlar için bir isim olsaydı yani taatlerin toplamı imanın kendisi olmuş olsayd1, bazı amellerin bulunmamasıyla imanın da olmaması gerekirdi. Oysa ibadetlerden önce ilk dönem nazil olan inançla ilgili hükümleri tasdik eden ve bunu ikrar eden kimsenin mümin olduğuna dair Müslümanlar arasında görüş birliği hâkimdir. ${ }^{44}$

Netice itibariyle Teftâzânî, amelin imanın meydana gelmesinin sebebi olmadığını, tam tersine ona bağlı olduğunu savunmaktadır. Ona göre amel, imanın tamlığa ve kemale ermesi bakımından etkisi ve faydası vardır. ${ }^{45}$ Bir mümin, kendisinde tasdikle çelişen bir durum arız olmadıkça imandan çıkmaz. Şehvetine, hiddet ve öfkesine, taassubuna veya tembelliğine ve ihmalkârlığına yenik düşerek büyük günah işlemek, tasdikle çelişen bir şey değildir. Fakat helal görerek ya da küçümseyerek bir günahı işlerse, onun bu davranışı tekzip/yalanlama alameti olacağından küfre girer. ${ }^{46}$ Zira Allah'ın haram kıldığı bir şeyi helal görmek, O'nu yalanlamak anlamına gelir. Yalanlamak da imanın özü olan tasdikle çelişir. ${ }^{47}$

40 İlgili ayetler için bk. el-Bakara 2/25, 82, 277; en-Nisâ 4/57, 122, 173; el-Mâide 5/9, 69, 93; el-A'râf 7/42; Yûnus 10/4, 9; Hûd 11/23; er-Ra'd 13/29; et-Tâhâ 20/75; el-Ankebût 29/7, 9; Lokmân 31/8; Fâtır 35/7; Fussilet 41/8; eş-Şûrâ 42/22; et-Tegâbün 60/9; elİnşikâk 84/25; el-Burûc 85/11; et-Tîn 95/6; el-Beyyine 98/7; el-Asr 103/3.

41 Teftâzânî, Tehzîbü'l-mantık ve'l-kelâm, 115.

42 Ebû Abdillah Fahruddîn er-Râzî, Mefâtihu'l-gayb, çev. Lütfullah Cebeci vd. (İstanbul: Huzur Yayınevi, 2013), 2/165.

43 el-En'âm 6/82; el-Enfâl 8/5, 72; el-Hucurât 49/9.

44 Teftâzânî, Şerhu'l-mekâsıd, 3/433, 434.

45 Teftâzânî, Şerhu'l-mekâsıd, 3/433, 435; Tehzîbü'l-mantık ve'l-kelâm,116.

46 Teftâzânî, Şerhu'l-'akâid, 250.

47 Teftâzânî, Şerhu'l-'akâid, 257. 
Mamafih günahkâr mümin, işlediği kötü/çirkin amellerden ötürü bir taraftan zemmi/yerilmeyi hak ediyor olsa da diğer taraftan kendisinde tüm taatların başı olan tasdik bulunduğundan övülmeye de layıktır. ${ }^{48}$ Esasında o kimsede günahlar geçici olduğundan cezasının da sürekli olmayıp geçici olması hikmete ve adalete uygundur. ${ }^{49}$ Dolayısıyla günahlarının varlığı, mümin olarak isimlendirilmeye engel değildir. Nasıl ki kâfir, sürekli küfür inancı taşıyorsa, mümindeki imanda devamlılık ve süreklilik hâlini ifade eder. ${ }^{50}$

Şu hâlde günahkâr mümin, tövbe etmeden ölmüş olsa bile cehennemde ebedî kalacak değildir. Zira Allah, "Kim zerre miktarı hayır yapmışsa onu görür."51 buyurmakla birlikte o kimsenin cehennemden çıkacağ 1 vaadinde ${ }^{52}$ bulunmaktadır. Teftâzânî nazarında hiçbir amel olmasa dahi kişideki kabul ve tasdikin kendisi bile yapılmış en faziletli ve değerli bir hayırdır. Ona göre ne kadar günah işlemiş olursa olsun bir mümin, bu hayrının karşılığını görecektir. Ancak o kimsenin önce cennette imanının mükâfatını alıp sonra cehenneme girmesi söz konusu değildir. Zira böyle bir şey, icmâya aykırıdır. Aksine ilahî af ve şefaate nail olmasa bile o kimse, cehennemde günahlarının cezasını çektikten sonra cennete girecektir. Aksi takdirde cehennemde ebedî kalmak, cezaların en ağırıdır. Küfrün bedeli olan bu ceza, kâfir olmayan bir kimseye verildiğinde ceza suçtan daha büyük olmuş olur ki bu durum, adalete terstir. ${ }^{53}$

Öte yandan Allah, şirkin haricinde, mümin kimselerden dilediğinin günahlarını bağışlayacağı müjdesini vermektedir. ${ }^{54}$ Açıkçası cezalandırmak Allah'ın bir hakkı olsa da vereceği cezayı kaldırmak da O'nun keremi ve merhametinin bir sonucudur. Nitekim bunun gerçekleşeceğine dair kimi ayetler, ${ }^{55}$ bu hususun sübutuna delalet eder. ${ }^{56}$ $\mathrm{Bu}$ ise her halükârda kullarının iyiliğini ve menfaatini düşünen

\footnotetext{
48 Teftâzânî, Şerhu'l-mekâsıd, 3/437.

49 Teftâzânî, Şerhu'l-'akâid, 254.

50 Teftâzânî, Şerhu'l-'akâid, 254.

51 ez-Zilzâl 99/7.

52 et-Tevbe 9/72; el-Kehf 18/107.

53 Teftâzânî, Şerhu'l-'akâid, 262.

54 en-Nisâ, 4/48, 116.

55 en-Nisâ, 4/48, 116; Hûd, 11/114; Zümer, 39/53; Şûrâ, 42/25, 30.

56 Teftâzânî, Mekâsıdu'l-kelâm fî 'akâidi'l-islâm, 696.
} 
532 | H. TÜRKMEN / Sa' düddîn Teftezânî'ye Göre Şefaatin İmkân ve Keyfiyeti

yaratıcının, günahkâr müminleri azapla tehdidinden vazgeçmesinin caiz olduğunu açıkça ortaya koyar.

\section{Teftâzânî'de Şefaat: Anlam Alanı ve Kapsamı}

Lügatte "benzeri olmayan tek" anlamindaki "وتر: vetr"in aksine tek olan bir şeye dengi veya benzerini ekleyerek birleştirmek ve onu ikili/çift kılmak manasına gelen şefaat, ${ }^{57}$ bir kimseye başkası nezdinde aracı olmak demektir. Daha doğrusu suçunun bağışlanması veya talebinin yerine getirilmesi için o kimseye aracı ve yardımcı olmaktır. ${ }^{58}$ Dinî terminolojide bu kavram, "günahkâr müminlerin affedilmesi, günahı olmayanların da derecelerinin yükseltilmesi için izin verilen kimselerin Allah nezdinde aracılık yapması" şeklinde tanımlanmaktadır..$^{59}$ Daha ziyade ahirete dönük etkisi açısından yapılan bu tanım, Müslümanlarca genel kabul görmüş ve zihinlerinde yer edinmiştir.

57 İsmail b. Hammâd el-Cevherî, es-Sihah tâcu'l-luga ve sihahu'l-'arabiyye, thk. Ahmed Abdulgafûr Attâr (Beyrut: Dâru'l-İlmi'l-Mâliyyîn, 1990), "ş-f-a", 3/1238; Halil b. Ahmed el-Ferâhîdî, Kitâbü'l-ayni müretteben alâ hurûfi'l-mu'cemi, thk. Abdülhamîd Hendâvî (Beyrut: Dârü'l-Kütübi'l-İlmiyye, 1424/2003), "ş-f-a", 2/342; Ebu'l-Huseyn Ahmed İbn Fâris, Mu'cemu mekâyisü'l-lüğati, thk. Abdüsselâm Muhammed Hârûn (Beyrut: Dârü'l-Fikr, 1399/1979), "ş-f-a", 3/201; Ebu'l-Kâsım Râgıb el-Isfahânî, elMüfredât fî garîbi'l-Kur'ân, çev. Abdulbaki Güneş - Mehmet Yolcu, (İstanbul: Çıra Yayınları, 2010), "ş-f-a", 555. Bu bağlamda iki şeyin bitişmesine delalet eden "شفع: şefe'a" fiili; "ب" edatıyla kullanıldığında, bir şeye ilave etmek ve katmak, bir şeyde öncelik tanımak; " "في "في "edatıyla kullanıldığında, birinin yararına ve lehine aracılık etmek; "الى" edatıyla kullanıldığında da, talepte bulunmak ve yardım istemek anlamlarına gelir. İbn Fâris, "ş-f-a", 3/201; Cemâluddîn Muhammed b. Mükerrem İbn Manzûr, Lisânü'l-'arab, thk. Abdullah Ali el-Kebîr vd. (Kahire: Dârü'l-Meârif, 1119), "ş-f-a", 4/2289; Ebu'l-Kâsım Cârullah ez-Zemahşerî, Esâsü'l-belâğati, thk. Muhammed Bâsil Uyûnü's-Sûd (Beyrut: Dârü'l-Kütübi'l-İlmiyye, 1419/1998), "ş-f-a”, 1/513. Bu fiilin masdarı olan "شفاعة: şefe'a" ise, yardım etmek ve hâlini sormak üzere başkasıyla bir araya gelmektir. Bu da daha ziyade itibar ve mertebe bakımından üst konumda olanın alt konumda olanla bir araya gelmesi tarzındadır. Nitekim ahiretteki şefaat de bu anlamdadır. el-Isfahânî, "ş-f-a", 555; İbn Manzûr, "ş-f-a", 4/2289. Yine bu fiilden türeyen "شفعة: şuf'a" da, kişinin ortağ1 olduğu satılık bir mülkü, satıldığ1 değer üzerinden kendi mülküne katması için onun üzerine hak talep etmesidir. Ali b. Muhammed eş-Şerîf el-Cürcânî, Kitâbü't-ta'rifât (Beyrut: Mektebetü Lübnan, 1985), “şuf'a", 133; el-Isfahânî, "ş-f-a", 556; İbn Manzûr, "ş-f-a", 4/2290.

58 İbn Manzûr, "ş-f-a", 4/2289.

59 Cürcânî, "şefa'at", 133; el-Isfahânî, "ş-f-a", 155; Topaloğlu - Çelebi, Kelâm Terimleri Sözlüğ̈̈, "Şefaat", 289. 
Esasında şefaatte temel gaye, kendisi için şefaat istenen kimsenin ihtiyacının karşılanmasıdır. Bu ihtiyaç, maddi veya manevi bir faydanın temini olabileceği gibi, kendisinden giderilmesini istediği bir zarar da olabilir. ${ }^{60}$ Tam da bu noktada -şefaati reddeden azınlık grubu bir kenara koyacak olursak- büyük günah işleyenlerin ahiretteki ahvaline dönük genel yaklaşımlar ekseninde geliştirilen söylem biçimleri, bilhassa şefaatin tesiri, faydası ve kimlere şefaat edileceği hususunda İslâm dünyasında ihtilaf ve çekişmelere neden olmuştur. Nitekim şefaatle bağışlamanın kesin olmayıp ihtimal ve olabilirlik içerdiğini söyleyerek ${ }^{61}$ konuya giriş yapan Teftâzânî, şefaatin hakikatinin zararlı olanın giderilmesi olduğunu belirtir. Onun açısından bu hakikat, aynı zamanda matlubun yani gerekli olanın ve istenilenin ispatı noktasında şefaatte aslolandır. ${ }^{62}$ Açık bir anlatımla şefaat, zarar ihtiva etmesi bakımından yalnızca büyük günahları değil küçük günahları da kapsamalıdır. Burada Teftâzânî, büyük-küçük fark etmeksizin zararın giderilmesi için Allah'tan talepte bulunmayı "matlubun ispatı" şeklinde kavramsallaştırmıştır.

Teftâzânî'ye göre, Mu'tezile, büyük günahlardan sakınılması hâlinde küçük günahların üzerinin örtüleceğini savunmaktadır. ${ }^{63}$ Onun nazarında ekolün böyle bir iddiası karşısında geriye sadece büyük günahlar kalmaktadır. Yani büyük günahlar kadar küçük günahlar da ilahî afv kapsamında değerlendirilmelidir. Diğer taraftan Teftâzânî'ye göre, Mu'tezile'nin iddia ettiği gibi şefaat, "menfaat talep etmek" anlamında kullanılmış olsaydı, Hz. Peygamber'e Allah'ın daha fazla ihsan ve keremde bulunmasını isterken elbette ona şefaat ediyor olurduk. Oysa onun açısından böyle bir şey asla söz konusu bile olamaz. ${ }^{64}$

60 Hacer Şahinalp, "Kâdî Abdülcebbâr ve Ebu'l-Muîn en-Nesefî'de Şefaat", Turkish Studies 13/25 (Fall 2018), 428.

61 Teftâzânî, şefaatin sadece büyük günah sahipleri için değil, küçük günah sahipleri için de mümkün olduğunu belirtir. Teftâzânî, Şerhu'l-mekâsıd, 3/399.

62 Teftâzânî, Mekâsıdu'l-kelâm fì 'akâidi'l-islâm, 700; Şerhu'l-mekâsıd, 3/398, 400; Tehzîbü'lmantık ve'l-kelâm, 111.

63 Mu'tezile, bu iddiasını Nisâ suresi 31. ayete dayandırmaktadır. Bu ayette Allah, büyük günahlardan kaçınıldı̆̆ı takdirde küçük günahların örtüleceğini bildirmektedir.

64 Teftâzânî, Mekâsıdu'l-kelâm fî 'akâidi'l-islâm, 700; Şerhu'l-mekâsıd, 3/398, 400; Tehzîbü'lmantık ve'l-kelâm, 111. 
Şefaatin aslının nass ve icmâ ile sabit olduğunu vurgulayan Teftâzânî, buna ilişkin ilk olarak Muhammed suresi 19. ayeti ${ }^{65}$ delil getirir. Ona göre umum ifade eden bu ayette Allah, peygamberine, erkek veya kadın olsun günahkâr müminlerin günahları için bağışlama dilemesini emretmektedir. Filhakika Allah'a yakınlaştırıcı ve müminler adına ümit verici olan bu bağışlama talebi, onların lehine azabın düşürülmesi için bir şefaattir. ${ }^{66}$ Diğer bir deyişle Hz. Peygamber, bu dünyada onların günahlarının mağfiretini sağladığ 1 gibi, ahiret hayatında da affı için devreye girerek şefaat etmesi akla aykırı olmayıp mümkündür. ${ }^{67}$ Buna karşın şayet günahkâr müminlere küfür izafe edilebilseydi, Hz. Peygamber onlar için istiğfarda bulunmazdı. Bilakis kimi ayetlerde ${ }^{68}$ onunla birlikte müminlerin, müşrik ve kâfirler için af dilemesi yasaklanmıştır. ${ }^{69}$ Dolayısıyla bu dünyada dua ve istiğfar için aklî temellendirme nasıl geçerli oluyorsa ahiret hayatındaki şefaat için de aynı durum son derece mümkündür. ${ }^{70}$

Teftâzânî nazarında şefaatin belli kimseler için hak ve sabit olduğunu gösteren diğer bir delil Müddessir suresi 48. ayettir.71 Ona göre bu ayetteki üslup ve ifade tarzı, bazı kimseler için şefaatin var olduğunu gösterir. Aksi halde kâfirlerin durumunu kötülemek ve ümitlerini boşa çıkarmayla kastedilen yerde onlara şefaatin fayda vermeyeceğini bildirmenin bir anlamı kalmaz. Ayrıca bu ayetin bağlamı, kâfirlerin yalnızca kendilerine özgü bir kısım özelliklerle nitelenmesini gerektirir. Yoksa ayette, onların kendilerini ve diğerlerini içine alan genel özelliklerle anılması kastedilmiş değildir. Dolayısıyla ayetteki kâfirlerle ilgili bu hükümden, onların dışında kalan müminlerin de şefaatçiye sahip olmayacağı manası çıkarılamaz. Bilakis şefaatçilerin şefaatinin, onlara fayda vereceğine delalet eder. ${ }^{72}$ Benzer şekilde Bakara

65 "... Hem kendinin hem de mümin erkeklerin ve mümin kadınların günahlarının bağışlanmasını dile..." Muhammmed 47/19. Ayrıca Hz. Peygamber'e hem kendisi hem de müminler için mağfiret dilemesinin emredildiği diğer ayetler için bk. Âl-i İmrân 3/159; en-Nisâ 4/64; Nûr 24/62; el-Mü'min 40/55; en-Nasr 110/3.

66 Teftâzânî, Şerhu'l-mekâsıd, 3/399; Tehzîbü'l-mantık ve'l-kelâm, 111.

67 Teftâzânî, Şerhu'l-'akâid, 259.

68 et-Tevbe 9/80, 84; el-Feth 48/11; el-Münâfikûn 63/6.

69 Cağfer Karadaş, "İslam Düşüncesinde Şefaat Nedir Ne Değildir?", Şefaat Nedir Ne Değildir?, ed. Adnan Demircan (Ankara: Fecr Yayınları, 2019), 123.

70 Teftâzânî, Şerhu'l-'akâid, 259.

71 "Artık şefaatçilerin şefaati onlara fayda vermez." el-Müddessir 74/48.

72 Teftâzânî, Şerhu'l-'akâid, 259. 
suresi 48. ayette $^{73}$ İsrailoğullarının küfür hâli yani yaptıkları işlerin çirkinliğine gönderme yapılarak onlar için ahirette şefaatin söz konusu olmayacağ 1 dile getirilmektedir. ${ }^{74}$ Böylelikle onların ümit ve beklentileri boşa çıkarılmıştır. Fakat bu hüküm, kâfirlerle beraber başkalarını da içine almaz ve sadece onları ilgilendirir. ${ }^{75} \mathrm{Bu}$ da demektir ki mefhum-u muhalifinden hareketle kendisinde en azından tamamlayıcıların temeli ve iyiliklerin özü olan iman bulunduğundan ${ }^{76}$ günahkâr kimse için şefaat mümkündür.

Bu ayetlerin dışında Teftâzânî'nin, kendi iddia ve kabulünü pekiştirme adına güçlü ve sağlam delil olarak gördügü yaygın bir hadîs bulunmaktadır. Aynı zamanda Ehl-i Sünnet âlimlerinin ${ }^{77}$ güvenip sımsıkı tutunduğu ve üzerinde fazlasıyla durduğu bu hadîs, kimi zaman "şüphesiz şefaatim, ümmetimden büyük günah sahipleri içindir"78 şeklinde, kimi zamanda "ümmetimden büyük günah işleyen kimselere şefaatimi sakladım"79 olarak farklı lafzı lafızlarla karşımıza çıkmaktadır. ${ }^{80}$ Ona göre bu hadîs, öncelikle her ne kadar âhâd haber olsa

73 "Öyle bir günden korkun ki, o günde hiç kimse başkası için herhangi bir ödemede bulunamaz; hiç kimseden şefaat kabul olunmaz, fidye alınmaz ve onlara asla yardım da yapılmaz." el-Bakara 2/48.

74 Rivayet edildiği üzere İsrailoğulları yani Yahudiler, peygamber olan atalarının kendilerine şefaat edeceklerini öne sürmüşlerdir. Bunun üzerine onların bu iddiasının asla gerçekleşmeyeceğini vurgulamak amacıyla bu ayet indirilmiştir. Abdullah b. Ahmed en-Nesefî, Medârikü't-tenzîl ve hakâiku't-te'vîl (Beyrut: Dârü'lKütübi'l-ìlmiyye, 1421/2001), 1/51.

75 Teftâzânî, Şerhu'l-mekâsıd, 3/399; Tehzîbü'l-mantık ve'l-kelâm, 111.

76 Teftâzânî, Şerhu'l-mekâsıd, 3/401.

77 Ehl-i Sünnet âlimlerinin şefaat hakkındaki görüş ve değerlendirmeleri için bakınız. Hasan Gümüşoğlu, “Ehl-i Sünnet'in Şefaat Anlayışının Oluşmasında İmam Mâtürîdî'nin Görüşlerinin Önemi", Ekev Akademi Dergisi 23/78 (Bahar 2019), 309-312.

78 "ان شفاعتي يوم القيامة لأهل الكبائر من أمتي" Ebû Dâvud, Sünnet, 20, 21; Tirmizî, Sıfatu'l-Kiyâme 11; Ahmed b. Hanbel, Müsned 213/3.

79 "ادخرت شفاعتي لأهل الكبائر من أمتي" Ebû Dâvud, Sünnet, 21; Tirmizî, Kryâmet 11; İbn Mâce, Zühd, 37; Ahmed b. Hanbel, Müsned, 213/3. Bu hadîs, başka bir lafızla şu şekilde nakledilir: "اني اختبئ دعوتي شفاعة لأمني يوم القيامة: şefaat davetimi kıyamet ümmetim için sakladım" Buhârî, Tevhîd, 31; Deavât, 1; Müslim, Îmân, 334, 345; Tirmizî, Deavât, 13; İbn Mâce, Zühd, 37; Dârimî, Siyer, 28; Rikâk, 85, Enes b. Mâlik, Kur'ân 26; Ahmed b. Hanbel, Müsned, 281/1, 295, 275/2, 381, 396, 426, 134/3, 208, 218, 219, 258, 276, 292, 384, 396, 145/5, 148. Teftâzânî, Şerhu'l-mekâsıd, 3/399 Dipnot.

80 Teftâzânî, Şerhu'l-'akâid, 260; Şerhu'l-mekâsıd, 3/398, 399. 
536 | H. TÜRKMEN / Sa' düddîn Teftezânî'ye Göre Şefaatin İmkân ve Keyfiyeti

da manen mütevâtir derecesinde meşhur olup tevatüre yakın kesinlik ifade eder. Burada Hz. Peygamber'in tövbe etmeyen günahkâr müminlere yönelik şefaat müjdesi söz konusudur. Öbür yandan Mu'tezile'nin iddia ettiği gibi bu hadîste, büyük günah işleyenlerden kasıt şayet tövbe edenler olmuş olsaydı, bunu Peygamberimiz açıkça belirtirdi. Hâlbuki farklı lafızlarla gelen bu hadîsin hiçbir rivayetinde böyle bir ifadeye rastlanmamıştır. Öyleyse bu hadîs, onların iddiasının aksine büyük günah işleyen müminlerin onun şefaatine erişeceği hususunda delil teşkil eder. ${ }^{81}$

Şu hâlde şefaatin tesirinin, azabı hak etmiş kimselerden azabın kaldırılması olarak tanımlayan Teftâzânî, yalnızca kebîre işleyenlerin değil küçük günah sahibi müminlerin de ya mahşer yerinde ya da cehennem ateşine girdikten sonra şefaata mazhar olup azaptan kurtulacaklarını belirtir. Zira doğrudan cennetlik olan müminlerin şefaate ihtiyacı yoktur. ${ }^{82}$

Mu'tezile, şefaati, itaatkâr ve tövbekâr mümin kimselerin derecelerinin yükseltilmesi ve sevaplarının artırılmasıyla sınırlayarak büyük günah sahiplerine afv ve şefaati imkânsız görmüşlerdir. Onlara göre Allah, adaleti ve hikmeti gereği fiillerinin tümü hasen olup asla kabîh/kötü ve çirkin fiil işlemez. Zira $O$, çirkin fiilin çirkinliğini bilmekte olup ondan müstağnidir ve bundan müstağni olduğunu da bilmektedir. Hâli bu olan kimsenin şu veya bu biçimde çirkin olana yönelmesi ve onu tercih etmesi söz konusu bile olamaz. Bu itibarla zulüm ve haksızlık gibi ilahlıkla bağdaşmayan fiiller kendisinde sadır olmaz. O, sadece insanların maslahatını gözeterek iyi ve güzel fiillerde bulunur. ${ }^{83}$ Dolayısıyla tövbe etmeden ölen kebâir sahibi kimseleri affetmek, hak etmedikleri ve layık olmadıkları bir lütufla onları mükâfatlandırmak demektir. Bu ise layık olana hakkını vermemekte olduğu gibi adalete mugayir çirkin bir davranıştır. ${ }^{84}$

Mu'tezilî kaynaklara rücu edildiğinde şefaat bahsi temelde, elva'd ve'l-va'îd ilkesi referans alınarak işlenmiş ve bu ilkenin zorunlu bir sonucu olarak görülmüştür. Nitekim müjde ve mükâfat içeren ayetlerde olduğu gibi tehdit ve korkutma ihtiva eden ayetler de kat'îdir ve umum

81 Teftâzânî, Şerhu'l-mekâsıd, 3/399.

82 Teftâzânî, Şerhu'l-mekâstd, 3/398, 400.

83 Kâdî Abdülcebbâr, Ahmed b. Halîl el-Hemedânî, Şerhu'l-'usûli'l-hamse, çev. İlyas Çelebi (İstanbul: Yazma Eserler Kurumu Başkanlığı Yayınları, 2013), 1/33; 2/8.

84 Şahinalp, "Kâdî Abdülcebbâr ve Ebu'l-Muîn en-Nesefî'de Şefaat", 425. 
ifade eder. Zira va'îdin umumî oluşu, günahkâr kimseye müstehak olduğu cezanın verileceğine delil olduğu gibi orada ebedî kalacağına da delildir. Kur'ân'da konuyla ilgili ayetlerin tamamında mutlaka hulûd, ebedîlik veya bunların yerine geçen bir ibareye rastlanmaktadır. Bu da Allah'ın hem vaad hem de va'îdinden asla dönmeyeceğinin açık kanıtı ve göstergesidir. Buna göre fasığın tövbe etmeksizin şefaate mazhar olması, Allah'ın va'îdinden dönmesi anlamına gelir. Oysa hak etmeyeni ödüllendirmek çirkin bir fiildir. Allah ise kötü ve çirkin olanı asla yapmaz. ${ }^{85}$

Görüldüğü üzere I'tizâlî perspektifte adl ve el-va'd ve'l-va'îd ilkeleri, beraberinde ahirette şefaatin olmamasını gerektirmektedir. Zira onlara göre şefaat adaletle örtüşmeyen bir tasarruf ve el-va'd ve'l-va'îd ilkesine aykırı bir uygulamadır. Öte yandan cezalandırma ve mükâfatlandırmanın sürekli olması gerektiği düşüncesinden hareketle ${ }^{86}$ iddialarını ispatlamak için kimi ayetleri birkaç yönden kanıt göstermişlerdir.

Bu kantlardan ilki, şefaatin tümüyle nefyine delalet eden ayetlerdir. Bu anlamda Bakara 48. ayetteki "hiç kimseden şefaat kabul olunmaz"87 sözü ile aynı surenin 123. ayetindeki beşer için genel müphemliği yansıtan "hiç kimseye şefaat fayda vermez"88 kavli ve yine aynı surenin 254. ayetinde iman edenlere yönelik Allah'ın, "kendisinde dostluk, alışveriş ve şefaatin olmadığ ${ }_{1}$ gün gelmeden önce size verdiğimiz rızıktan hayır yolunda harcayın"89 hitabı ve ikazıdır.90 Yine Gâfir (Mü'min) suresi 18. ayette Allah, ${ }^{91}$ açıcça zalimlerin ne dostu ne de sözü dinlenir herhangi bir şefaatçilerinin bile olmayacağını

85 Kâdî Abdülcebbâr, Şerhu'l-'usûli'l-hamse, 1/34; 2/574.

86 Kâdî Abdülcebbâr, Şerhu'l-'usûli'l-hamse, 2/576.

87 " el-Bakara 2/48.

88 " el-Bakara 2/123.

89 "el-Bakara 2/254. أيها الذين آنموا....من قبل أن يأتى يوم لا بيع فيه ولا خلة ولا شفاعة...

90 Mu'tezile'ye göre bu gibi ayetlerin hükümleri kat'î olmakla beraber lafızları umum ifade eder. Nitekim ayetlerin siyak ve sibakı ile konu bütünlüğü dikkate alındığında onları tahsis edecek/sınırlandıracak bir delil bulunmamaktadır. Kâdî Abdülcebbâr, Şerhu'l-'usûli'l-hamse, 2/606.

91 "Yaklaşan gün hususunda onları uyar. Çünkü o onda dehşet içinde yutkunurken yürekleri ağızlarına gelmiştir. Zalimlerin ne dostu ne de sözü dinlenir şefaatçisi vardır." el-Mü'min 40/18. 
bildirmektedir. Başka bir deyişle $\mathrm{O}$, zalimler için şefaatçi olmasını kesin olarak nefyetmektedir. Şayet Hz. Peygamber zalimlere şefaat edici olsaydı, onlardan daha yüce, önemli ve kıymetli olmazdı. ${ }^{92}$ Aynı minvalde Mâide suresi 72 . ayette ${ }^{93}$ de zalimlerin asla yardımclarının olmayacağ1 buyrulmaktadır. ${ }^{94}$ Mu'tezile'ye göre bu ayetlerde geçen şefaat kelimesi, nekre olduğundan nefy sîgasında genellik ifade eder. Bu da tövbe etmeden fısk üzere ölen kişilere şefaatin hiçbir türünün kabul edilmemesi ve fayda vermemesi demektir. Aksi takdirde hak etmeyeni ödüllendirmek anlamına gelir $\mathrm{ki}$, bu fiil çirkin olup böyle bir fiili Allah'ın işlemesi düşünülemez. ${ }^{95}$ Zira $\mathrm{O}$, çirkin fiilin çirkinliğini bildiğinden onu işlemekten münezzehtir. ${ }^{96}$ Dolayısıyla şefaat, icmâ üzere yalnızca itaat eden ve tövbe eden kimseye hasredilir. ${ }^{97}$

Teftâzânî, Mu'tezile'nin ayetlere ilişkin bu ifade açıklamalarını, sübjektif, keyfî ve mesnetsiz yorumlar olarak değerlendirir. Ona göre şefaatin olmadığına dair genellik ifade ettiği söylenen ayetlerin tüm ahval ve zamanları kapsadığ 1 kabul edilse dahi şefaatin varlığını ortaya koyan diğer ayetlerle bir araya getirilip bir bütün olarak değerlendirildiğinde bu ayetler, kâfirlere tahsis edilir. Zira ayetlerde geçen mutlak zulüm, küfürdür. Keza yardımın olmaması da şefaatin nefyini gerektirmez..$^{98}$ Kuşkusuz şefaat, boyun eğme üzerine bir taleptir. Yardım ise, bir nevi koruma ve galip gelmeyi haber vermedir. Bu da sözü, her ne kadar olumsuzu genelleştirmek için kullanıldığı kabul edilse bile asla geneli olumsuz kılmak için değildir. ${ }^{99}$

Mu'tezile'nin şefaatin tümüyle nefyine dair öne sürdüğü ayetler hakkındaki Teftâzânî'nin bu değerlendirmeleri, yüzeysel, sığ ve genelleştirici bir yaklaşımı çağrıştırmaktadır. Her şeyden önce mezhebî

92 Kâdî Abdülcebbâr, Şerhu'l-'usûli'l-hamse, 2/606.

93 "Yemin olsun ki 'Allah, kesinlikle Meryem oğlu Mesîh'tir' diyenler kâfir olmuşlardır. Hâlbuki Mesîh 'Ey İsrailoğulları! Rabbim ve Rabbiniz olan Allah'a kulluk ediniz. Biliniz ki kim kendisine ortak koşarsa muhakkak Allah ona cenneti haram kılar; artık onun yeri ateştir ve zalimler için yardımcılar yoktur' demişti." el-Mâide 5/72.

94 Teftâzânî, Şerhu'l-'akâid, 260; Mekâsıdu'l-kelâm fî 'akâidi'l-islâm, 700; Şerhu'l-mekâsıd, 3/398, 400-401.

95 Kâdî Abdülcebbâr, Şerhu'l-'usûli'l-hamse, 2/606.

96 Kâdî Abdülcebbâr, Şerhu'l-'usûli'l-hamse, 2/8.

97 Teftâzânî, Şerhu'l-mekâsıd, 3/400.

98 Teftâzânî, Şerhu'l-'akâid, 260; Mekâsıdu'l-kelâm fì 'akâidi'l-islâm, 700; Şerhu'l-mekâsıd, 3/398, 401.

99 Teftâzânî, Şerhu'l-mekâsıd, 3/401. 
taassubu yansitan bu tavriyla Teftâzânî, çokça eleştirdiği bu ekolün içine düştüğü yanlışa bilerek veya farkında olmadan maalesef kendisi de düşmüştür. Zira tartışma konusu yaptığı ayetlerin her birini ayrı ayrı ele almak yerine, onları mensubu olduğu mezhebin genel söylemi doğrultusunda kategorize edici totalci bir bakış sergilemektedir. Oysa bunun yerine ayetleri, konu bütünlügünün yanı sıra iç ve dış bağlamı hesaba katarak Kur'ân'ın dünya görüşüyle ters düşmeyecek biçimde ele alması sağduyulu, doğru ve yerinde bir davranış olacaktır. Bunu yaparken de ön yargı ve bağımlılıktan uzak biçimde tarafsız ve tutarlı bir yöntem izlenmesi olmazsa olmazdır. Yoksa ayetlerin vermek istediği mesaj net, açık ve anlaşılır olmaktan uzak hale gelir ve muhatabı belirsizliğe sürükler.

Mu'tezile'nin ikinci delili, kebîre sahibine afv ve şefaatin olmayacağını ifade eden ayetlerdir. ${ }^{100}$ Onlara göre, büyük günah sahibi için şefaatin nefyedilmesiyle hissedilenin "Allah'ın rızasına ulaşmış olanlardan başkasına şefaat etmezler"101 kavlinde olduğu gibi kebîre sahibinin Allah'ın razı olduğu kimse olmadı̆̆ının lafız olarak söylenmesidir. ${ }^{102}$ Başka bir deyişle Allah, şefaatini Cennet Ehli için onlar üzerindeki nimetlerini, iyilik ve lütfunu artırarak gerçekleştirecektir.103 Ayrıca Arş'ı yüklenen Meleklerden bahseden ayette geçen "tövbe eden ve senin yolundan gidenleri bağ $1 s ̧ l a " 104$ ifadesinde olduğu gibi, tövbe etme ve Hz. Peygamber'in yoluna uyma birlikte zikredilmiş ve afv için bu ikisi şart koşulmuştur. $\mathrm{Bu}$ da kebîre sahibinden şefaatin nefyedilmesini sezdirmektedir. Zira böyle bir kimse, Allah'ın kendisinden razı olmadığı kişidir. ${ }^{105}$ Kuşkusuz kâfir ve müşrikler gibi tövbe etmeden ölen günahkârlar da Allah'ın razı olmadığı kimseler olduğundan şefaate nail olamazlar. Nasıl ki başkasının çocuğunu öldüren ve başkasının da kendisini öldürmesini bekleyen kişiye şefaat kabîh bir fiil ise tövbe etmeden fısk üzere ölen kişilere şefaat de aynı

\footnotetext{
100 Teftâzânî, Mekâsıdu'l-kelâm fì 'akâidi'l-islâm, 700; Şerhu'l-mekâsıd, 3/399.

101 " el-Enbiyâ 21/28.

102 Kâdî Abdülcebbâr, Şerhu'l-'usûli'l-hamse, 2/606.

103 Kâdî Abdülcebbâr, Fadlü'l-I'tizâl ve tabakâtü'l-Mu'tezile, nşr. Fuâd Seyyid (Tunus: Dârü't-Tûnisiyye, 1393/1974, 211; Şahinalp, "Kâdî Abdülcebbâr ve Ebu'l-Muîn enNesefî'de Şefaat", 431.

104 el-Mü'min 40/7.

105 Teftâzânî, Şerhu'l-mekâsıd, 3/401.
} 


\section{0 | H. TÜRKMEN / Sa' düddîn Teftezânî'ye Göre Şefaatin İmkân ve Keyfiyeti}

ölçüde kötü ve çirkin bir iştir. Hak etmeyeni ödüllendirmek çirkin bir iş olduğundan bu kişiler, cennete lütuf olarak giremezler. ${ }^{106}$ Zaten Gâfir (Mü'min) suresi 7. ayette açıkça ifade edildiği üzere Arş'ı yüklenen ve onun çevresinde bulunanlar, Allah'tan sadece tövbe eden ve kendi yolunda giden müminlerin bağışlanmasını isterler. Burada onların bağışlanmasını isteyen ve şefaate aracı olanların, peygamberler ve melekler olması arasında bir ayırım söz konusu değildir. ${ }^{107}$ Dolayısıyla şefaat, kâfirler, müşrikler ve fısk üzere ölen günahkârlar için değil sadece kendilerinden razı olunan ve birçok nimetlere erişmiş cennetlikler için geçerlidir. ${ }^{108}$

Mu'tezile'nin bu bilgi ve yorumuna karşın Teftâzânî, fâsığın her ne kadar günahı cihetinden nefret edilen olsa da kendisinde bulunan iman ve sâlih amel bakımından razı olunan kimse olduğunu belirtir. Bunun aksine zulümle nitelenen kâfir ise, tamamlayıcıların esası ve hasenatın aslı olan iman kendisinde bulunmadığından Allah'ın razı olduğu kimse değildir. Bu yüzden Gâfir (Mü'min) suresi 7. ayetteki "tövbe edenler" sözünün, fasıkları kapsamadığı kabul edilemez. Buradaki sözden kasıt, şirkten tövbe eden kimselerdir. Zira Mu'tezile nazarında, günahlardan tövbe edip sâlih amel işleyenlerin için mağfiret talebi anlamsız ve gereksizdir. Yahut böyle bir şey, hak edene hakkını vermemekten kaynaklanan zulmü bırakmayı istemedir.109 Kaldı ki bu bile, onun dişında kalan şeyin hükmünün nefyi üzere nitelenen tahsise delalet eder. ${ }^{110}$

Tövbe etmeden ölen günahkârlar için şefaatin olmayacağ1 iddiasıyla ilgili Mu'tezile'nin üçüncü delili, fâsıkların cehennem ateşinde sonsuza değin kalacağını ifade ettiğini zannettikleri ayetlere dayanmaktadır. Onlara göre, Nisâ suresi $14 .{ }^{111}$ ve 93 . ayetlerin ${ }^{112}$ yanı

\footnotetext{
106 Kâdî Abdülcebbâr, Şerhu'l-'usûli'l-hamse, 2/606.

107 Teftâzânî, Şerhu'l-mekâsıd, 3/401.

108 Kâdî Abdülcebbâr, Şerhu'l-'usûli'l-hamse, 2/606.

109 Teftâzânî, Mekâsıdu'l-kelâm fî̀ 'akâidi'l-islâm, 700; Şerhu'l-mekâsıd, 3/399, 401.

110 Teftâzânî, Şerhu'l-mekâsıd, 3/401.

111 "Kim Allah'a ve Resûlüne karşı isyan eder ve sınırlarını aşarsa Allah onu, devamlı kalacağ 1 bir ateşe koyar ve onun için alçaltıcı bir azap vardır." en-Nisâ 4/14.

112 "Kim bir mümini kasten öldürürse cezası, içinde ebediyen kalacağı cehennemdir. Allah ona gazap etmiş, onu lanetlemiş ve onun için büyük bir azap hazırlamıştır." en-Nisâ 4/93.
} 
sıra Secde suresi 20. âyet ${ }^{113}$ ile Zümer suresi 19. ayet ${ }^{114}$ ve Cin suresi 23. ayet, ${ }^{115}$ küfür ve şirke düşenler ile diğer büyük günah işleyenlerin ebediyen cehennemde azap göreceğini ve onları Hz. Peygamber'in bile kurtaramayacağına delalet eder. ${ }^{116}$ Keza günahkârların ebedî olarak cehenneme sevk edilip oradan çıkmalarının imkânsızlığını vurgulayan İnfitâr sûresi 14 ila 16. ayetlerin ${ }^{117}$ yanı sıra Bakara suresi 81. âyet, ${ }^{118}$ fâsığın sürekli azaba uğrayacağını bildirir. ${ }^{119} \mathrm{Mu}^{\prime}$ tezile tarafından fâsığın cehennemde ebedî kalacağına ve orada devamlı azap göreceğine delil olarak getirilen bu ayetler, va'îdin umumiliği yani ebedî azapla tehdidin genel oluşunu gösterir. Zira bu esas, o kimseye hak ettiği cezanın verileceğine delil olduğu gibi, orada ebedî kalacağına da delildir. Bu esasla ilintili olarak örnek verilen ayetlere dikkatle bakıldığında, hepsinde mutlaka hulûd/süreklilik, te'bîd/ebedî kılma veya bunların yerine geçen başka bir ibare zikredilmektedir. ${ }^{120}$

Teftâzânî'ye göre, delil getirilen ayetlerin sîgaları her ne kadar umum ifade etse de $^{121}$ bu ayetler ya kâfirlere ya helal görerek kötülükleri kasten işlemeye ya da kesintili uzun süre kalmaya tahsis edilir. ${ }^{122}$ Nitekim Cin sûresi 23. âyette, umum kastedilmeyip tövbe eden ve küçük günah işleyenler hariç tutulmuştur. Zira böyle kimseler, ittifakla ebedî olarak cehennemde kalmazlar. Bu durumda âmm nassın tahsisi kesinliği ortadan kaldıracağ i için kebîre işleyen kimse de bu ayetin umumundan yani genel hükmünden çıkarılmalıdır. Ayrıca cehennem ateşine müstehak olma, Meryem suresi 75. ayetteki "dalalet içinde olanların

113 "Fâsıklar ise, onların varacakları yer ateştir. Oradan her çıkmak istediklerinde geri çevrilirler ve kendilerine, 'yalanladığınız azabı tadın!' denilir." es-Secde 32/20.

114 "(Resulüm!) Hakkında azap hükmü gerçekleşmiş kimseyi ve ateşte olanı sen mi kurtaracaksın?" es-Zümer 39/19.

115 "...Artık kim Allah ve Resûlüne karşı gelirse, bilsin ki ona, içinde ebedî kalacağı cehennem ateşi vardır." el-Cin 72/23.

116 Kâdî Abdülcebbâr, Şerhu'l-'usûli'l-hamse, 2/606.

117 "Facirler kesinlikle cehennemdedirler. Ceza gününde oraya girerler. Onlar, oradan bir daha ayrilmazlar." el-İnfitâr 82/14-16.

118 "...Kim bir kötülük yapar da kötülüğü kendisini çepeçevre kuşatırsa işte o kimseler cehennemliktirler. Onlar orada devamlı kalırlar." el-Bakara 2/81.

119 Teftâzânî, Şerhu'l-'akâid, 263; Mekâsıdu'l-kelâm fì 'akâidi'l-islâm, 688; Şerhu'l-mekâsıd, 3/379, 383; Tehzîbü'l-mantık ve'l-kelâm, 109.

120 Kâdî Abdülcebbâr, Şerhu'l-'usûli'l-hamse, 2/574.

121 Teftâzânî, Şerhu'l-mekâsıd, 3/379, 383.

122 Teftâzânî, Tehzîbü'l-mantık ve'l-kelâm, 109. 
kendilerine vaad olunan azabı veya kıyameti gördükleri zaman"123 kavlinde olduğu gibi, ebedî azapla tehdidi görme gayesine matuftur. Zaten bir sonraki ayette, "sonunda tehdit edildikleri azabı görünce..."124 buyurulmuştur. Şayet bu kabul edilse bile ebedî azaba müstehak olma, ebedî azabın gerçekleşmesini zorunlu kılmaz. ${ }^{125}$

Nisâ suresi 93. âyette, "bir mümini taammüden öldürmeden" kasit, İbn Abbas'ın tefsiri üzere, "helal sayarak o kimseyi imanı yüzünden öldürme" manasındadır. Bunu yapan kimsenin de kâfir olduğu gayet açıktır. ${ }^{126}$ Bunun dışında ayetteki "hulûd" lafzından kastedilen, uzun süre kalmadır. Bu lafzın, sonsuzluğu teyit anlamında bir hakikat olduğu söylenemez. Nitekim "biz, senden önce de hiçbir beşere ebedîlik vermedik..."127 ‘ayetinde olduğu gibi, bu ayette geçen "hulûd" lafzı için de sonsuzluk anlamı akla gelmemelidir. Zira bir şeyi tekit, medlulünü güçlendirmek içindir. Bu lafızla ilgili genel ifadeler, kâfirleri içine alır. Onlar hakkında ittifakla sonsuzluk kastedilir. Sonsuzluk anlamı verilen bu lafzın süreklilik anlamında hakikat olduğunun istidlali, "müebbet hapis", "ebedî vakıf" deyimiyle çelişir. Kuşkusuz bu iki deyimde, sürenin uzunluğu kastedilir. Her ne kadar yaygın olan kullanımda devamlılık anlamı hemen akla gelen bir söz olmasa da bu ayette, kesintili uzun süre kalma anlamında kullanılmıştır. Şu hâlde bu lafız, mecaz ve iştirakten nefyedilerek kesintili uzun süre kalma manasına hamledilir. Diğer taraftan uzun süre kalma, ister hakikî isterse mecazî manaya hamledilsin, kâfirler hakkında olduğunda sürekli olmakla beraber genelleştirilir. Büyük günah işleyen kimseler hakkında ise, sınırlama söz konusu olup o kimseler için sona erme yani kesintili uzun süre kalma anlamı belirlenmiştir. ${ }^{128}$

Mu'tezile tarafından delil getirilen bir diğer ayet olan Secde suresi 20. ayet hakkında Teftâzânî, bu ayetteki fasıklardan kastın, haşrı inkâr eden kâfirler olduğunu belirtir. Ona göre bunun karinesi, hem ayetin devamında yer alan "yalanlamakta olduğunuz cehennem azabını

\footnotetext{
123 "حتى اذا رأوا ما يوعدون اما العذاب واما الساعة" Meryem 19/75.

124 el-Cin 72/24.

125 Teftâzânî, Mekâsıdu'l-kelâm fî̀ 'akâidi'l-islâm, 690; Şerhu'l-mekâsıd, 3/379, 383.

126 Teftâzânî, Şerhu'l-'akâid, 264; Şerhu'l-mekâsıd, 3/379, 384.

127 " el-Enbiyâ 21/34.

128 Teftâzânî, Şerhu'l-'akâid, 264; Şerhu'l-mekâsıd, 3/383, 384.
} 
tadın"129 kavlidir. ${ }^{130}$ Yine facirlerden bahseden İnfitâr 14 ila 16. ayetler, tüm ferdi nefyetmeyi ifade ettiği kabul edildikten sonra bulunmanın devamina delalet eder. Ne var ki ayn surenin 9. ayetinden ${ }^{131}$ itibaren konu bütünlüğü ve sözün akışı dikkate alınıp deliller bir araya getirildiğinde, bu ayetler yalnızca kâfirlere tahsis edilir. ${ }^{132}$ Buna göre 16. âyetteki "onların cehennemden ayrılmaması"133 sözü, ya herkes için geçerli değildir yahut "hulûd" lafzında olduğu gibi, uzun üzere kalma manasında bir mübalağadır. ${ }^{134}$ Keza Bakara suresi 81. ayet de İslâm'ın sınırlarını aşmaya ve hatanın kişiyi esir alıp kuşatmasına hamledilir. Nitekim bunların varlığı, o kişide imanın kalmaması anlamına gelir. ${ }^{135}$ $\mathrm{Bu}$ ise onun ebedî olarak cehennem ateşinde kalmasını gerektirir. ${ }^{136}$ Dolayısıyla tüm bu ayetler, günahkâr müminler hakkında değil, kâfirlere özgüdür. ${ }^{137}$ Zaten onların cehennem ateşinde ebedî kalacağ1 hususunda da görüş ayrılığ bulunmamaktadır. ${ }^{138}$

Bu çerçevede Teftâzânî, büyük günah işleyip tövbe etmeden vefat eden mümin kimselerin, azap göreceği ya da affedileceği hakkında kesin bir şey söylenemeyeceğini ve bu anlamda Allah'ın dilerse onları affedeceğini dilerse de azap edeceğini vurgular. Fakat azaba uğratma ihtimali üzere o kimseler cehennemde ebedî kalmazlar. Zira Kur'ân'da, özellikle iman edenlerin amellerinden bir şey eksiltilmeyeceği ve herkese kazandıklarının karşılığının verileceği bildirilmektedir. ${ }^{139} \mathrm{Bu}$ nedenle mutlaka oradan çıkarılırlar. ${ }^{140} \mathrm{Bu}$ ise her ne kadar Allah'in üzerine vacip değilse de vaadinin gereği olarak yapacaktır. ${ }^{141}$ Kuşkusuz

\footnotetext{
129 es-Secde 32/20.

130 Teftâzânî, Şerhu'l-mekâsıd, 3/384.

131 "Hayır, siz dini yalanlıyorsunuz" el-İnfitâr 82/9.

132 Teftâzânî, Şerhu'l-mekâsıd, 3/384.

133 " el-İnfitâr 82/16.

134 Teftâzânî, Mekâsıdu'l-kelâm fî̀ 'akâidi'l-islâm, 690; Şerhu'l-mekâsıd, 3/379.

135 Teftâzânî, Mekâsıdu'l-kelâm fî̀ 'akâidi'l-islâm, 690; Şerhu'l-mekâsıd, 3/379, 384.

136 Teftâzânî, Şerhu'l-mekâsıd, 3/384.

137 Teftâzânî, Şerhu'l-'akâid, 264.

138 Teftâzânî, Tehzîbü'l-mantık ve'l-kelâm, 109.

139 İlgili ayetler için bk. et-Tûr 52/21; en-Necm 53/41; el-Kamer 54/52-53; en-Nebe' 78/29; ez-Zilzâl 99/7-8.

140 Teftâzânî, Şerhu'l-'akâid, 262; Şerhu'l-mekâsıd, 3/378, 381, 397; Tehzîbü'l-mantık ve'lkelâm, 110.

141 Teftâzânî, Şerhu'l-mekâsıd, 3/378, 381, 393.
} 
vaatten dönülmesi, ittifakla kerem vasfına yakışmayan bir kötülük ${ }^{142}$ olduğundan $\mathrm{O}$, asla vaadinden dönmez ve ona bağlllık gösterir. ${ }^{143}$ Nitekim ayet ${ }^{144}$ ve hadîsler, ${ }^{145}$ kebîre sahibi kimselerin ya affa uğrayarak $^{146}$ cennete gideceğini ya da cezasının karşıllı̆ını çektikten sonra cehennemden çıkarılıp cennete konulacağına delalet eder. ${ }^{147}$

Cehennemde ebedî kalmak, cezaların en ağırı ve azabın en şiddetlisidir. Bu nedenle böyle bir ceza, suçların en büyügü olan küfrün karşılığ kılınmıştır. ${ }^{148}$ Kuşkusuz küfür, zaman ve miktar bakımında sınırlı değildir. ${ }^{149}$ Buna karşın küfür dışındaki diğer günahların cezası ise küfürle eşdeğer ve aynı değildir. ${ }^{150}$ Çünkü günah, miktar ve zaman bakımından sınırlıdır. Cezası da adalet esasına bağlı olarak sonlu ve sınırlı olmalıdır. ${ }^{151}$ Şayet cehennemde ebedî kalma cezası kâfir olmayan bir kimseye verilirse, o takdirde ceza suçtan daha büyük olmuş olur ve

142 Teftâzânî, Şerhu'l-mekâsıd, 3/395.

143 Teftâzânî, Şerhu'l-mekâsıd, 3/393, 394; Tehzîbü'l-mantık ve'l-kelâm, 108. Bu kapsamda Allah'ın vaadinden dönmeyeceğine delalet eden ayetler için bk. el-En'âm 6/134; elAhkâf 46/17; Muhammed 47/15; Kâf 50/29; ez-Zâriyât 51/5, 23; et-Tûr 52/28

144 en-Nisâ 4/124; et-Tevbe 9/72; el-Kehf, 18/107. Teftâzânî'ye göre, Âl-i İmrân 3/185 ve el-En'âm 6/128. ayetler de cehennem ateşinden çımayı hissettiren nasslar arasındadır. Teftâzânî, Şerhu'l-mekâsıd, 3/382.

145 Hz. Peygamber, "lâ ilâhe illallah diyen kimse cennete girer" (Buhârî, İlim 49; Müslim, Îmân, 47, 53; Ebû Dâvud, Cenâiz, 20) ve "her kim zina eden ve hırsızlık yapan olsa da herhangi bir şeyi Allah'a şirk koşmadan vefat ederse cennete girer" (Buhârî, Cenâiz, 10; Bedü'l-Halk, 6; Libâs, 24; İsti'zân, 30; Rikâk, 13, 14; Tevhîd, 33; Müslim, Îmân, 153, 154; Zekât, 32, 33; Tirmizî, Îmân 18, Ahmed b. Hanbel, Müsned, 152, 159, 161, 285, 166/6, 442) müjdesini vermiştir. Bu minvalde Allah Resûlü, "ömründe imandan başka bir hayrı olmayan bir topluluk cehenneme doldurulup kömürleştikten sonra oradan çıkar ve nehir kıyısında biten taneler gibi yeniden hayat bulurlar (Buhârî, Ezan, 129; Rikâk, 52; Tevhîd, 24; Müslim, Îmân 299, 304; Dârimî, Mukaddime 8; Ahmed b. Hanbel, Müsned, 23/1, 276/2, 534, 56/3, 144, 326, 391/5, 402). Teftâzânî'ye göre bu hadîs, her ne kadar âhâd haber olduğundan asıllarda/itikadî konularda delil olmasa da, nassların birbirini desteklemesiyle teyit ve tekit ifade eder. Teftâzânî, Şerhu'lmekâsıd, 3/382.

146 Teftâzânî, Şerhu'l-mekâsıd, 3/384.

147 Teftâzânî, Mekâsıdu'l-kelâm fí 'akâidi'l-islâm, 688; Şerhu'l-'akâid, 262; Şerhu'l-mekâsıd, 3/378, 381, 397.

148 Teftâzânî, Şerhu'l-'akâid, 262; Şerhu'l-mekâsıd, 3/382.

149 Teftâzânî, Şerhu'l-mekâsıd, 3/382.

150 Teftâzânî, Şerhu'l-mekâsıd, 3/382.

151 Teftâzânî, Şerhu'l-mekâsıd, 3/379. 
bu, adalete aykırıdır. ${ }^{152}$ Öyle ki bir mümin yüz sene ibadet ve sâlih amel üzere hayatını sürdürse ve bu esnada bir yudum içki içse, adaleti ve hikmeti gereği Allah'ın bu kimseyi ebedî olarak cezalandırması doğru değildir. Aksi halde böyle bir şey, zulüm olur. ${ }^{153}$

Teftâzânî'ye göre Mu'tezile, ebedî azapla tehdidin kulu günahlardan sakındırma adına onun iyiliğine bir lütuf olduğunu ileri sürer. Aksi takdirde o kimse günaha dalarak ondan haz duymaya başlar ve azabı dikkate almaz. Buna bağlı olarak da o kimsenin, taatlerin yerine getirilmesi hususunda kayıtsız kalması ve duyarsızlaşması söz konusu olup geleceği açısından karanlığa sürüklenmesi kuvvetle muhtemeldir. Ancak Teftâzânî, onların bu iddiasına karşı çıkarak cennet vaadinin, iman ehli için bir lütuf ve günahlara karşı bir engelleyici olduğunu savunur. Tam aksine kâfirler için ebedî azap bir lütuf ve hikmetli olandır. ${ }^{154}$

Teftâzânî nazarında, herhangi bir kimseye zararı olmaksızın cezalandırmak kula faydalı olsa da, hakkı olan bu cezayı Allah'ın bağ 1 şlamasi ${ }^{155}$ hasendir. ${ }^{156}$ Zira fayda yönünü içermesi ve husün türleriyle irtibatlı olması hâlinde günahkâr müminler için tehdidinden vazgeçmesi mümkündür. ${ }^{157} \mathrm{Bu}$ nedenle dilemesine bağlı olarak O'nun böyle kimseleri affetmesi, onlara karşı lütüf ve keremde bulunması anlamına gelir. ${ }^{158}$ Nitekim O'nun afv ve gafûr sıfatıyla ${ }^{159}$ bağışlamanın vuku bulacağına dair açık ve anlaşılır ayetler ${ }^{160}$ ve hadîsler ${ }^{161}$

152 Teftâzânî, Şerhu'l-'akâid, 262; Şerhu'l-mekâsıd, 3/382.

153 Teftâzânî, Şerhu'l-mekâsıd, 3/382; Tehzîbü'l-mantık ve'l-kelâm,109.

154 Teftâzânî, Şerhu'l-mekâsıd, 3/385.

155 Teftâzânî'ye göre bağışlamanın manası, özür dileme olmaksızın suçluya verilmesi gereken cezadan vazgeçilmesi ve onun üzerinin örtülmesidir. Teftâzânî, Şerhu'lmekâsıd, 3/392.

156 Teftâzânî, Şerhu'l-mekâsıd, 3/392.

157 Teftâzânî, Şerhu'l-mekâsıd, 3/396.

158 Teftâzânî, Şerhu'l-mekâsıd, 3/393, 394.

159 Allah'ın çokça bağışlayan ve affeden oluşunu ifade eden ayetler için bakınız. en-Nisâ 4/23, 25, 96, 99, 100, 106, 110, 129, 149, 152; el-Mâide 5/3, 9, 34, 39, 74, 101; el-En'âm 6/54, 145, 165; Nûr 24/22, 26; Fussilet 41/43; eş-Şûrâ 42/5, 23, 30, 34; Muhammed 47/15; el-Fetih 48/14, el-Hucurât 49/3, 5, 14; el-Hadîd 57/20, 21, 28; el-Mücadele 58/2, 12; el-Mümtehine 60/7; es-Saf 61/12; et-Tegâbün 64/4; et-Tahrîm 66/1; el-Mülk 67/1, 12; Nuh 71/10; ez-Müezzemmil 73/20; el-Müddessir 74/56.

160 en-Nisâ 4/48, 116; el-Mâide 5/15; er-Ra'd 13/6, eş-Şûrâ 42/25, 30, 34; ez-Zümer 39/53. Teftâzânî'ye göre bu ayetlerin, küçük günahları affa ya da tövbeden sonra büyük 
546 | H. TÜRKMEN / Sa' düddîn Teftezânî'ye Göre Şefaatin İmkân ve Keyfiyeti

bulunmaktadır. ${ }^{162}$ Tüm bunlar, ne kadar günah işlerse işlesin bir müminin kendisinde bulunan imanının mükâfatını alacağını ${ }^{163}$ ve buna bağlı olarak şefaate nail olacağını gösterir. ${ }^{164}$

Verilen bu bilgi ve açıklamalardan anlaşılacağı üzere Teftâzânî, kebîre sahibi mümin kimselerin şefaat beklentisini, günahlarından ötürü ilahî lütuf ve ikramın artmasını istemelerinin bir tezahürü olarak görmektedir. Aynı zamanda ona göre şefaat, o kimselere yönelik son bir

günahları affetmeye yahut müstehak olunan cezaları ertelemeye, günahların geneline had cezaları koymamaya, önceki toplumlarda olduğu gibi helak edici sorumluluklar yüklememeye, kimi toplulukların hükmü ortadan kaldırılan fiillerini yapmamaya, veyahut alınlarına suçlarını/günahlarını yazmamaya ve bunun gibi ayıp ve kusurlarını ortaya dökerek dünyada rezil etmemeye hamledilmesi, delil olmaksızın nassların zahirinden ayrılmak anlamına geldiği gibi karinesiz genelleştirme ve tahsis edilen olmaksızın genelin tahsisi anlamına gelir. Ayrıca müfessirlerin görüşlerine ve sahih hadîslerin sarîh beyanlarına da aykırıdır. Bu noktada bir aykırılık söz konusu değildir. Zaten Nisâ 48 ile 116. ayetlerde olduğu gibi, kimi nasslar için bu teviller ne doğrudur ne de mümkündür. Zira tövbeyle Allah'ın günahları affetmesi, şirk dışındaki günahlara tahsis edilemez. Kuşkusuz O, tövbeyle şirki de affeder. Yine küçük günahlarda olduğu gibi tövbeden sonra affı meşiete yani O'nun dilemesine bağlamak da uygun olmaz. Nitekim bu ayetlerde, kötü ve çirkin işlerde nihayete ulaşmayı ifade eden şirkle, korkutma amaçlanmaktadır. Öyle ki şirk tövbesiz affedilmez. Onun dışındaki kabîh fiillerin hepsini dilerse ve isterse affeder. Ta ki ne kadar çok büyük günah olursa olsun. Teftâzânî, Mekâsıdu'l-kelâm fì 'akâidi'l-islâm, 690; Şerhu'l-mekâsıd, 3/391, 392.

161 Hz. Peygamber, "lâ ilâhe illallah diyen kimse cennete girer" (Buhârî, İlim, 49; Müslim, Îmân, 47, 53; Ebû Dâvud, Cenâiz, 20) ve "her kim zina eden ve hirsızlık yapan olsa da herhangi bir şeyi Allah'a şirk koşmadan vefat ederse cennete girer" (Buhârî, Cenâiz, 10; Bedü'l-Halk, 6; Libâs, 24; İsti'zân, 30; Rikâk, 13, 14; Tevhîd, 33; Müslim, Îmân, 153, 154; Zekât, 32, 33; Tirmizî, Îmân, 18, Ahmed b. Hanbel, Müsned, 152, 159, 161, 285, 166/6, 442) müjdesini vermiştir. Yine Allah Resûlü, "ömründe imandan başka bir hayrı olmayan bir topluluk cehenneme doldurulup kömürleştikten sonra oradan çıkar ve nehir kıyısında biten taneler gibi yeniden hayat bulurlar (Buhârî, Ezan, 129; Rikâk, 52; Tevhîd, 24; Müslim, Îmân, 299, 304; Dârimî, Mukaddime 8; Ahmed b. Hanbel, Müsned, 23/1, 276/2, 534, 56/3, 144, 326, 391/5, 402) diyerek amellerin en faziletlisi ve Allah katında en değerlisi olan imanın kendisinin bile cehennemden çıkmaya tek başına yeteceğini ve böylece ne kadar çok günah işlerse işlesin günahkâr müminin er ya da geç cehennem ateşinden çıacağını beyan etmektedir. Teftâzânî, Şerhu'l-'akâid, 262.

162 Teftâzânî, Şerhu'l-mekâsıd, 3/391, 392; Tehzîbü'l-mantık ve'l-kelâm, 110-111.

163 Teftâzânî, Şerhu'l-'akâid, 262; Şerhu'l-mekâsıd, 3/392.

164 Teftâzânî, Şerhu'l-'akâid, 261. 
umut ve af kapısıdır. Zira bu şekilde bir bağışlama, Allah'ın engin rahmet ve kereminin sonucu ve gereğidir. Bu minvalde Mu'tezile dışındaki diğer İslâm fırkalarının şefaatin varlı̆̆ı yönündeki itifakı, onun nazarında günahkârların azaptan kurtarılma ihtiyaç ve talebinin iletilmesinin ötesinde bir mana taşımaz.

\section{Sonuç}

Şefaat konusu, İslam dünyasında iman ile amel arasındaki ilişki türüyle doğrudan ilintili biçimde tartışılmış ve değerlendirilmiştir. Şefaati kabul eden düşünce ekollerinin bilhassa konuyu ele alırken başvurdukları ve tutundukları iki teori gözlerden kaçmamaktadır. İlki, $\mathrm{Mu}$ 'tezile tarafindan savunulan istihkak yani hak etme keyfiyeti teorisi, diğeri de Ehli Sünnet tarafından öne sürülen kurtuluş teorisi yani vesilelere yönelerek çıkış yolu arama girişimidir. Nitekim şefaati bir afv vesilesi olarak gören Ehli Sünnet âlimleri, imanın başlı başına bir kurtuluş yolu olduğunu ve buna bağlı olarak kurtuluş imkânının her daim mevcut olduğunu ve şefaatin de bu imkânlardan biri olduğunu vurgularlar. Ancak onlara göre bu imkân, kesin ve garanti olmayıp ihtimal ve olabilirlik içerir.

Mamafih Teftâzânî, şefaat hakkında müntesibi olduğu ekolün bu genel söylemini bir adım ileri taşıyarak şefaatle bağışlamanın, Allah'ın lütuf, kerem ve rahmetinin bir sonucu ve gereği olduğunu dile getirir. Açıkçası meseleye dair bu sözüyle diğer Ehli Sünnet'in genel yaklaşımından kısmen de olsa farklı bir tutum sergileyerek bu şekilde bağışlanmanın kesin ve garanti olduğu izlenimi ve algısı uyandırmaktadır. Oysa ulûhiyetini, yegâneliğini ve hükümranlığını hiç kimseyle paylaşmayan Allah, bu konuda son sözü söyleyecek tek karar merciidir. Dolayısıyla tüm fiil ve tasarruflarında kendisinin hesaba çekilmesi ve sorgulanması söz konusu olmadı̆̆ı gibi, ahiret âleminde karşılaşacağımız hüküm ve sonuç da yalnızca O'na aittir.

Şefaat meselesinin, bireysel ve toplumsal açıdan iyiliği özendirme ve kötülükten sakındırmadaki rolü ve etkisinin ortaya konması, meselenin ilahî sıfatlar ekseninde tartışılmasından daha fazla kıymetli ve önemlidir. Zira bu mesele özelinde tespit ve açıklamalarda bulunulurken yaratıcının asıl muhatabı ve hedef kitlesi olan insanın tabiatı, karakteri ve manevî ihtiyaç ve talepleri göz ardı edilemez. Her ne kadar bireysel farklılıklar gereği kimi insan cezadan kaçma eğilimli kimileriyse mükâfat elde etme eğilimli olsa da yapısı itibariyle her insan 


\section{8 | H. TÜRKMEN / Sa' düddîn Teftezânî'ye Göre Şefaatin İmkân ve Keyfiyeti}

rahatlığa, gevşemeye ve nefsinin esiri olmaya daha çok yatkındır. Azap ve korkutma olmadığı sürece bu durum, keyiflerine ve çıkarlarına düşkün olan insanları daha fazla kötülük yapmaya ve sâlih amellere karşı ilgisiz ve kayıtsız kalmaya sevk etmektedir. Bunun için ilahî emir ve yasakların yerine getirilmesi hususunda bir taraftan insanları teşvik ve motive edici ödül vaat edilirken, aslolan onları kötülüklerden alıkoyup iyiliğe yönelmelerini sağlayacak caydırıcı cezalara, uyarı ve korkutmalara ihtiyacın varlığı kaçınılmazdır. Zaten Kur'ânda, insanların bu yapısal özellikleri ve ruh halleri dikkate alınmış ve onlara hitap edilirken azap ile korkutma ve mükâfat ile teşvik bir yöntem ve yaklaşım tarzı olarak takip edilmiştir.

Bir taraftan cennet vaadi ile afv ve şefaat inanc1, mümin kimse için teşvik edici, cesaretlendirici ve motive edici bir fonksiyona sahip olmalıdır. Bunun dışında diğer taraftan da ahirete yönelik uyarı ve tehditler, her şeyden önce o kimseye sorumluluk ve hesap verme duygusu kazandırmalı ve böylelikle ilahî hükümlere karşı hassasiyet ve özen göstermelidir. Aksi hâlde ibadet ve sâlih amellerden yoksun bir iman, zayıflamaya ve sonunda sönüp kaybolmaya mahkûmdur. Bu yüzden af, mağfiret ve şefaat beklentisi içerisinde sadece Allah'in inayeti ve rahmetine sığınılmamalı ve bunlar garanti ve kesin olarak görülmemelidir. Tabiatıyla bu tutum, bireysel ve toplumsal ölçekte ahlâkî yozlaşmaya ve çöküşe neden olabileceği gibi, amellere karşı tembelliğe, ihmalkârlığa ve duyarsızlığa da sevk edebilir. Oysa tüm yaşamı ve davranışları kuşatan yönüyle iman, bütüncül, dinamik ve aktif şahsiyet oluşturma amacına dönük olup zihinsel, duygusal, kalbî ve bedensel unsurları içine almak zorundadır.

\section{Kaynakça}

Barlak, Muzaffer. “İbn Teymiyye'nin Felsefî Yöntem Eleştirisi ve Müslüman Filozofları Tekfir Etme Gerekçeleri". The Journal of Academic Social Science Studies 13/81 (Güz 2020), 363-378.

Cevherî, İsmail b. Hammâd. es-Sihah tâcu'l-luga ve sihahu'l-'arabiyye. thk. Ahmed Abdulgafûr Attâr. 7 Cilt. Beyrut: Dâru'l-İlmi'l-Mâliyyîn, 4. Basım, 1990.

Cürcânî, Ali b. Muhammed eş-Şerîf. Kitâbü't-ta'rifât. Beyrut: Mektebetü Lübnan, 1985. 
Gümüşoğlu, Hasan. “Ehl-i Sünnet'in Şefaat Anlayışının Oluşmasında İmam Maâtürîdî'nin Görüşlerinin Önemi". Ekev Akademi 23/78 (Bahar 2019), 299-314.

Ferâhîdî, Halil b. Ahmed. Kitâbü'l-ayni müretteben alâ hurûfi'l-mu'cemi. thk. Abdülhamîd Hendâvî. 4 Cilt. Beyrut: Dârü'l-Kütübi'l-îlmiyye, 1424/2003.

Isfahânî, Ebu'l-Kâsım Râgıb. el-Müfredât fì garîbi'l-Kur'ân. çev. Abdulbaki Güneş - Mehmet Yolcu. İstanbul: Çıra Yayınları, 2. Basım, 2010.

İbn Fâris, Ebu'l-Huseyn Ahmed. Mu'cemu mekâyisü'l-lüğati. thk. Abdüsselâm Muhammed Hârûn. 6 Cilt. Beyrut: Dârü'l-Fikr, 2. Basım, 1399/1979.

İbn Manzûr, Cemâluddîn Muhammed b. Mükerrem. Lisânü'l-'arab. thk. Abdullah Ali el-Kebîr vd.. 6 Cilt. Kahire: Dârü'l-Meârif, 1119.

Kâdî Abdülcebbâr, Ahmed b. Halîl el-Hemedânî. Fadlü'l-İ'tizâl ve tabakâtü'l-Mu'tezile, nşr. Fuâd Seyyid. Tunus: Dârü't-Tûnisiyye, 1393/1974.

Kâdî Abdülcebbâr, Ahmed b. Halîl el-Hemedânî. Şerhu'l-'usûli'l-hamse. çev. İlyas Çelebi. 2 Cilt. İstanbul: Yazma Eserler Kurumu Başkanlığı Yayınları, 2013.

Karadaş, Cağfer. "İslam Düşüncesinde Şefaat nedir Ne Değildir?". Şefaat Nedir Ne Değildir?. ed. Adnan Demircan. 107-148. Ankara: Fecr Yayınları, 2019.

Nesefî, Abdullah b. Ahmed. Medârikü't-tenzîl ve hakâiku't-te'vîl. 2 Cilt. Beyrut: Dârü'l-Kütübi'l-İlmiyye, 1421/2001.

Râzî, Ebû Abdillah Fahruddîn. Mefâtihu'l-gayb. çev. Lütfullah Cebeci vd.. 23 Cilt. İstanbul: Huzur Yayınevi, 2013.

Şahinalp, Hacer. "Kâdî Abdülcebbâr ve Ebu'l-Muîn en-Nesefî'de Şefaat". Turkish Studies 13/25 (Fall 2018), 421-445.

Teftâzânî, Mes'ûd b. Ömer b. Abdullah eş-Şehîr bi Sa'duddîn. Mekâsıdu'l-kelâm fî̀ 'akâidi'l-islâm. çev. İrfan Eyibil. İstanbul: Türkiye Yazma Eserler Kurumu Başkanlı̆̆ı Yayınları, 2019.

Teftâzânî, Mes'ûd b. Ömer b. Abdullah eş-Şehîr bi Sa'duddîn. Şerhu'l'akâid. çev. Talha Hakan Alp. İstanbul: Marmara Üniversitesi İlahiyat Vakfı Yayınları, 4. Basım, 2017.

Teftâzânî, Mes'ûd b. Ömer b. Abdullah eş-Şehîr bi Sa'duddîn. Şerhu'lmekâsıd. thk. İbrâhîm Şemsüddîn. 3 Cilt. Beyrut: Dârü'l-Kütübi'lİlmiyye, 2. Basım, 2011. 
550 | H. TÜRKMEN / Sa'düddîn Teftezânî'ye Göre Şefaatin İmkân ve Keyfiyeti

Teftâzânî, Mes'ûd b. Ömer b. Abdullah eş-Şehîr bi Sa'duddîn. Tehzîbü'lmantık ve'l-kelâm. thk. Şeyh Abdülkâdir Ma'rûf el-Kürdî. Misır: Matbaatü's-Saa'de, 1330/1912.

Topaloğlu, Bekir - Çelebi, İlyas. Kelâm Terimleri Sözlüğü. İstanbul: İSAM Yayınları, 4. Basım, 2015.

Türkmen, Hasan. "Şemsuddîn es-Semerkandî'de Îman-Amel İlişkisi". Aksaray Üniversitesi İslami İlimler Fakültesi Dergisi 4/7 (2017 Haziran), 21-39.

Zemahşerî, Ebu'l-Kâsım Cârullah. Esâsü'l-belâğati. thk. Muhammed Bâsil Uyûnü's-Sûd. 2 Cilt. Beyrut: Dârü'l-Kütübi'l-İlmiyye, 1419/1998. 